\title{
Apolipoprotein E Proteinopathy Is a Major Dementia-Associated Pathologic Biomarker in Individuals with or without the APOE Epsilon 4 Allele
}

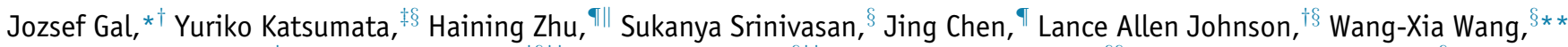
Lesley Renee Golden, ${ }^{\dagger}$ Donna M. Wilcock, ${ }^{\dagger \dagger \dagger \dagger}$ Gregory A. Jicha, ${ }^{\S \ddagger \dagger}$ Matthew D. Cykowski, ${ }^{\S \S}$ and Peter Tobias Nelson ${ }^{\S * *}$

From the Spinal Cord and Brain Injury Research Center (SCoBIRC), * Department of Neuroscience, ${ }^{\dagger}$ Department of Biostatistics, ${ }^{\ddagger}$ Sanders-Brown Center on Aging, ${ }^{\S}$ Department of Molecular and Cellular Biochemistry, ${ }^{\top}$ Department of Pathology, ${ }^{* *}$ Department of Physiology, ${ }^{\dagger \dagger}$ and Department of Neurology, ${ }^{\ddagger \ddagger}$ University of Kentucky, Lexington, Kentucky; Research \& Development, "Lexington VA Medical Center, Lexington, Kentucky; and Houston Methodist Hospital, ${ }^{\S \S}$ Houston, Texas

Accepted for publication November 24, 2021.

Address correspondence to Peter Tobias Nelson, M.D., Ph.D., Division of Neuropathology, Department of Pathology, Sanders-Brown Center on Aging, University of Kentucky, Rm 311, 800 S. Limestone St., Lexington, KY 40536-0230. E-mail: peter. nelson@uky.edu.

\begin{abstract}
The amygdala is vulnerable to multiple or "mixed" mis-aggregated proteins associated with neurodegenerative conditions that can manifest clinically with amnestic dementia; the amygdala region is often affected even at earliest disease stages. With the original intent of identifying novel dementiaassociated proteins, the detergent-insoluble proteome was characterized from the amygdalae of 40 participants from the University of Kentucky Alzheimer's Disease Center autopsy cohort. These individuals encompassed a spectrum of clinical conditions (cognitively normal to severe amnestic dementia). Polypeptides from the detergent-insoluble fraction were interrogated using liquid chromatography-electrospray ionization-tandem mass spectrometry. As anticipated, portions of peptides previously associated with neurologic diseases were enriched from subjects with dementia. Among all detected peptides, Apolipoprotein E (ApoE) stood out: even more than the expected Tau, $A P P / A \beta$, and $\alpha$-Synuclein peptides, ApoE peptides were strongly enriched in dementia cases, including from individuals lacking the APOE \&4 genotype. The amount of ApoE protein detected in detergent-insoluble fractions was robustly associated with levels of complement proteins $\mathrm{C} 3$ and $\mathrm{C} 4$. Immunohistochemical staining of $A P O E \quad \varepsilon 3 / \varepsilon 3$ subjects' amygdalae confirmed ApoE co-localization with $C 4$ in amyloid plaques. Thus, analyses of human amygdala proteomics indicate that rather than being only an "upstream" genetic risk factor, ApoE is an aberrantly aggregated protein in its own right, and show that the ApoE protein may play active disease-driving mechanistic roles in persons lacking the APOE \&4 allele. (Am J Pathol 2022, 192: 564-578; https://doi.org/10.1016/ j.ajpath.2021.11.013)
\end{abstract}

Typically, the brains of persons who died with amnestic dementia harbor multiple aberrantly aggregated proteins. ${ }^{1-3}$ In prior studies that discovered the now widely recognized dementia-associated misfolded proteins (eg, Tau and $A \beta$ ), those polypeptides were isolated from the detergentinsoluble protein fraction. ${ }^{4-6}$ The amount of detergentinsoluble pathogenic proteins (DIPPs) in the aged brain at autopsy has been consistently correlated with cognitive impairment before death. ${ }^{7-10}$

Complementing clinical-pathologic correlation studies, genetic research has provided important insights into disease-driving mechanisms. The genes that encode each of the common neurodegenerative disease (ND)-associated DIPPs (APP, MAPT, SNCA, and TARDBP) may, when mutated, cause NDs. However, only an extremely small minority of ND cases are caused by those genetic mutations.

Supported by NIH grants P30 AG072946 (P.T.N. and Dr. Linda Van Eldik), R01 AG042419 (P.T.N.), R01 AG042475 (P.T.N.), R01 AG061111 (P.T.N.), R01 AG057187 (P.T.N.), R21 AG061551 (P.T.N.), RF1 NS118584 (M.D.C.), R01 AG060056 (L.A.J.), R01 AG062550 (L.A.J.), and R21 NS095299 (J.G.); and the VA MERIT award I01 BX002149 (H.Z.). The Orbitrap mass spectrometer was acquired by NIH Grant S10 RR029127 (H.Z.).

Disclosures: None declared. 
The ND-associated genetic risk factor with the largest known public health impact is the APOE $\varepsilon 4$ allele. (In this publication, the apolipoprotein $\mathrm{E}$ gene is referred to as $A P O E$ and the cognate protein as ApoE.) Compared with the more common $A P O E \& 3$ allele, the APOE \&4 gene variant is defined by a nucleotide substitution inducing a cysteine $\rightarrow$ arginine amino acid change in the ApoE protein. $^{11}$

The APOE \&4 allele is associated with an increased risk for Alzheimer disease (AD) neuropathologic change, Lewy body diseases, and limbic-predominant age-related TDP-43 encephalopathy neuropathologic change. ${ }^{12-16}$ Differing mechanisms have been proposed by which the riskassociated $A P O E$ \&4 polymorphism may cause or exacerbate ND pathophysiology. ${ }^{17}$ For example, the APOE $\varepsilon 4$ allele may promote altered processing of the other misfolded protein(s), may stimulate deleterious neuroinflammation, and/or may have an adverse impact on brain lipid processing. ${ }^{18,19}$ ApoE immunostaining in amyloid plaques and Tau tangles has been reported, and a gain-of-toxic ApoE protein function has been hypothesized in $\mathrm{AD} .{ }^{11,17}$

Although APOE pathobiology is a very active area of scientific investigation, whether the ApoE protein participates in ND pathogenesis among individuals who lack the $A P O E \varepsilon 4$ allele is presently unknown. This is a potentially important issue because most persons with NDs lack the $A P O E$ risk allele. More specifically, whereas the APOE $\varepsilon 4$ risk allele is present in approximately $25 \%$ of individuals in most human populations, ${ }^{17,20}$ approximately $75 \%$ of persons of advanced age have at least some AD-type pathology. ${ }^{21,22}$ Thus, well over one-half of persons with AD-type pathology lack the $A P O E$ risk allele.

Driven at least partly by genetic factors, dementia-related diseases tend to affect specific vulnerable anatomic regions, expanding through the brain in a stereotypic manner. The biological phenomena underlying the region-specific anatomic vulnerability are still mostly unknown. However, a common paradigm has emerged: the amygdala and immediate peri-amygdala regions of the human brain harbor misfolded proteins early in the course of multiple NDs. ${ }^{23-29}$ For example, even in cognitively unimpaired individuals, the amygdala region often contains the following: pathologic Tau (neurofibrillary tangles) and $\mathrm{A} \beta$ (amyloid plaques) peptide, which signal incipient $\mathrm{AD}$ neuropathologic change; $\alpha$-Synuclein aggregates that herald Lewy body diseases; and/or TDP-43 proteinopathy that indicates limbic-predominant age-related TDP-43 encephalopathy neuropathologic change. ${ }^{12,25,28,30,31}$ For these reasons, the amygdala may be a special source of fresh insights into biologic phenomena relevant to early ND pathogenesis. Candidate amygdala DIPPs were previously studied from individuals who had been followed up to autopsy with tissue available at the University of Kentucky AD Research Center biobank. ${ }^{32}$

This study reports the results of additional amygdala proteomics studies with a larger sample of cases and controls from the University of Kentucky AD Research Center biobank. Consistent with prior work, expected dementiaassociated DIPPs are present in amygdala and enriched in the brains of individuals with documented antemortem cognitive impairment. In the present study, there was clear evidence that the ApoE protein is a conspicuous dementiaassociated misfolded polypeptide in the amygdala, even among individuals lacking the $A P O E \& 4$ risk allele.

\section{Materials and Methods}

\section{Fractionation of Amygdala Proteins from Autopsy Brains}

Research protocols including consent forms were approved by the University of Kentucky Institutional Review Board, and all research volunteers consented to research autopsies. Details regarding the recruitment of University of Kentucky AD Research Center research volunteers, as well as clinical and pathologic assessments, have been described previously. ${ }^{33-37}$ Research participants with unusual dementia syndromes (eg, prions or trinucleotide repeat diseases) or brain tumors were excluded. Information was also obtained on agonal events for each subject, and additional criteria for exclusion from the study were an extended interval of premortem hypoxia, any medical ventilator use, brain edema, or large infarct. A convenience sample of cases was selected from among autopsies with a postmortem interval $<5$ hours. Dissected amygdalae were snap-frozen in liquid nitrogen at autopsy and then stored at $-80^{\circ} \mathrm{C}$ until these experiments were performed.

Protein sample fractionation followed the published methodology of Sampathu et al, ${ }^{38}$ with some modifications. Each amygdala was weighed, then homogenized in $5 \mathrm{~mL}$ of low-salt (LS) buffer [10 mmol/L TRIS-HCl, pH7.5, $5 \mathrm{mmol} /$ L EDTA, and 10\% (w/v) sucrose] per gram tissue using tissue grinders (\#47732-446; VWR, Radnor, PA). The homogenates were centrifuged at $25,000 \times \mathrm{g}, 4^{\circ} \mathrm{C}$ for 30 minutes, and the supernatants saved as the LS fractions. The pellets were re-extracted with LS buffer, centrifuged as above, and the supernatants were discarded. The pellets were extracted with $5 \mathrm{~mL}$ TX buffer [LS buffer supplemented with $1 \%(\mathrm{v} / \mathrm{v})$ Triton-X-100 and $0.5 \mathrm{~mol} / \mathrm{L} \mathrm{NaCl}]$ per gram original tissue, centrifuged at $180,000 \times g, 4^{\circ} \mathrm{C}$ for 30 minutes, and the supernatants saved as the TX fractions. The pellets were re-extracted with TX buffer, centrifuged as above, and the supernatants were discarded. The pellets were extracted with $5 \mathrm{~mL}$ myelin flotation buffer (TX buffer containing $30 \%[\mathrm{w} / \mathrm{v}]$ sucrose) per gram original tissue, centrifuged at $180,000 \times g, 4^{\circ} \mathrm{C}$ for 30 minutes, and the supernatants were discarded. The pellets were extracted with $5 \mathrm{~mL}$ SARC buffer (LS buffer supplemented with $1 \%$ [w/v] $\mathrm{N}$-lauroylsarcosine and $0.5 \mathrm{~mol} / \mathrm{L} \mathrm{NaCl}$ ) per gram original tissue, incubated at $22^{\circ} \mathrm{C}$ for 2 hours on an end-over-end shaker, centrifuged at $180,000 \times g, 22^{\circ} \mathrm{C}$ for 30 minutes, and the supernatants were saved as the SARC fractions. The pellets were extracted with $0.75 \mathrm{~mL}$ urea buffer $[7 \mathrm{~mol} / \mathrm{L}$ 
urea, $2 \mathrm{~mol} / \mathrm{L}$ thiourea, $4 \%$ (w/v) CHAPS, and $30 \mathrm{mmol} / \mathrm{L}$ TRIS-HCl, $\mathrm{pH}$ 8.5] per gram original tissue at $22^{\circ} \mathrm{C}$, centrifuged at $25,000 \times g, 22^{\circ} \mathrm{C}$ for 30 minutes, and the supernatants saved as the urea soluble fractions. The LS, TX, SARC, and myelin flotation buffers were supplemented with protease inhibitor cocktail (P8340, 1:300; Millipore Sigma, Burlington, MA), phenylmethylsulfonyl fluoride $(0.2 \mathrm{mmol} / \mathrm{L}), N$-ethylmaleimide $(5 \mathrm{mmol} / \mathrm{L})$, nicotinamide $(20 \mathrm{mmol} / \mathrm{L})$, trichostatin A $(1.5 \mu \mathrm{mol} / \mathrm{L})$, sodium orthovanadate $(1 \mathrm{mmol} / \mathrm{L})$, and PhosSTOP phosphatase inhibitor tablets (1 tablet per $10 \mathrm{~mL}$; 4906837001; Millipore Sigma). The LS, TX, SARC, and myelin flotation homogenates were supplemented with $1 \mathrm{mmol} / \mathrm{L}$ DL-dithiothreitol immediately before centrifugation, and the supernatants were saved with SDS-PAGE loading buffer and heated at $94^{\circ} \mathrm{C}$ for $5 \mathrm{mi}-$ nutes. The urea (ie, detergent-insoluble) fractions were saved similarly but without heating to avoid protein carbamoylation.

\section{Liquid Chromatography-Electrospray Ionization- Tandem Mass Spectrometry and Data Analysis}

The processing of the amygdalae and the generation and analysis of the mass spectrometric data were performed in a blinded fashion (ie, without the experimenter knowing which samples represented cognitively normal control subjects and which represented patients with dementia). All mass spectra reported in this study were acquired at the University of Kentucky Proteomics Core Facility (https:// www.research.uky.edu/proteomics-core-facility; last accessed October 27, 2021). Equal total protein amounts of the detergent-insoluble fractions were resolved by denaturing SDS-PAGE on $4 \%$ to $12 \%$ Bis-TRIS gradient protein gels (catalog \#NP0335BOX; Thermo Fisher Scientific, Waltham, MA) using MES SDS Running Buffer (catalog \#NP0002; Thermo Fisher Scientific), followed by staining with Sypro Ruby protein gel stain (catalog \#S-12000; Molecular Probes, Eugene, OR). Gel pieces were cut above the $171 \mathrm{kDa}$ protein molecular weight marker band followed by dithiothreitol reduction, iodoacetamide alkylation, and ingel trypsin digestion. The resulting tryptic peptides were extracted, concentrated, and subjected to liquid chromatography-tandem mass spectrometry (LC-MS/MS) analysis as previously described. ${ }^{39,40}$ Briefly, LC-MS/MS analysis was performed by using an LTQ-Orbitrap mass spectrometer (Thermo Fisher Scientific) coupled with a cHiPLC-nanoflex system (Eksigent, Dublin, CA) through a nano-electrospray ionization source. The peptide samples were separated with a reversed-phase cHiPLC column $(75 \mu \mathrm{m} \times 150 \mathrm{~mm})$ at a flow rate of $300 \mathrm{~nL} / \mathrm{min}$. Mobile phase A was water with $0.1 \%$ (v/v) formic acid, and mobile phase $\mathrm{B}$ was acetonitrile with $0.1 \%(\mathrm{v} / \mathrm{v})$ formic acid. A 50-minute gradient condition was applied: initial 3\% mobile phase B was increased linearly to $40 \%$ in 24 minutes and further to $85 \%$ and $95 \%$ for 5 minutes each before it was decreased to $3 \%$ and re-equilibrated.

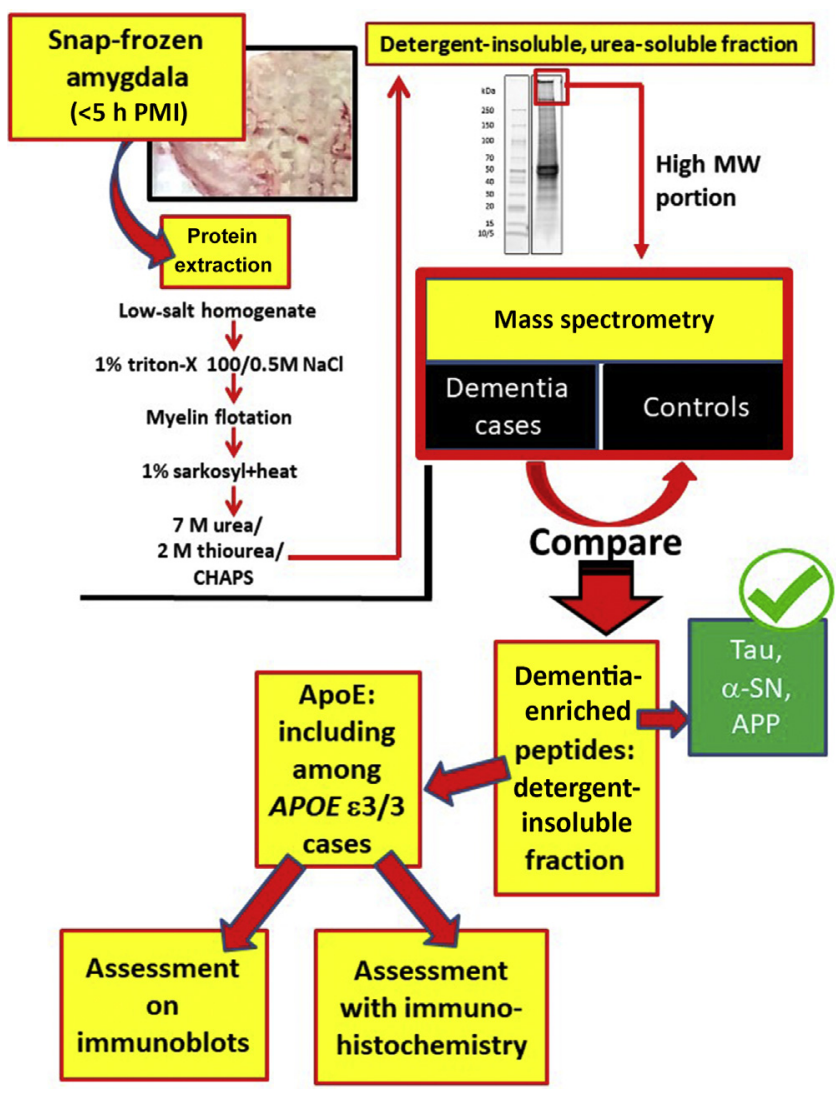

Figure 1 Overview of study design and experiments performed. With the goal of identifying detergent-insoluble pathogenic proteins (DIPPs) enriched in dementia brains, experiments began with protein fractionation followed by comparison of high molecular weight (MW), urea-soluble (detergent-insoluble) proteins from cognitively impaired and control subjects. Optimally, a novel DIPP candidate would be more likely to be present in a preparation that was found to also contain established DIPPs: Tau, $\alpha$-Synuclein, and/or amyloid precursor protein (APP). Apolipoprotein E $(\mathrm{ApoE})$ emerged as being highly enriched in the detergent-insoluble fraction, and follow-up experiments were performed with immunoblots and immunohistochemistry. PMI, postmortem interval.

LC-MS/MS data were acquired in an informationdependent acquisition mode. Each data collection cycle consisted of 11 scan events: one Orbitrap mass spectrometer scan (300 to $1800 \mathrm{~m} / \mathrm{z}$ ) with 60,000 resolution for parent ions followed by MS/MS for fragmentation of the 10 most intense ions using collision-induced dissociation.

The LC-MS/MS data referent to gel slices were submitted for MS/MS protein identification using the MASCOT algorithm via Proteome Discoverer (version 1.3; Thermo Fisher Scientific), applying a database containing human protein sequences from Uniprot ${ }^{41}$ (last downloaded February 2, 2020). Parameters used in the MASCOT MS/MS ion search were: trypsin digestion with maximum of two missed cleavages, cysteine carbamidomethylation, and methionine oxidation. Posttranslational modifications were also examined in MASCOT searches, including lysine acetylation, 
Table 1 Summary Data for Included Case and Control Subjects

\begin{tabular}{|c|c|c|c|c|c|c|c|}
\hline Case \# & Age, years & Sex & Final MMSE score & Final clinical diagnosis & Braak NFT score & APOE genotype & ApoE MS results \\
\hline 1308 & 85 & $\mathrm{~F}$ & 28 & Normal & II & $2 / 3$ & 0 \\
\hline 1298 & 96 & $\mathrm{~F}$ & 24 & Dementia & VI & $2 / 3$ & 36.4 \\
\hline 1068 & 92 & $\mathrm{~F}$ & 22.5 & Dementia & VI & $2 / 3$ & 51.1 \\
\hline 5388 & 87 & $\mathrm{~F}$ & 28 & MCI & I & $3 / 3$ & 0 \\
\hline 1313 & 79 & $\mathrm{~F}$ & 26 & Normal & I & $3 / 3$ & 0 \\
\hline 1293 & 86 & $\mathrm{~F}$ & 29 & Normal & $\mathrm{I}$ & $3 / 3$ & 0 \\
\hline 1312 & 94 & M & 25 & Normal & II & $3 / 3$ & 0 \\
\hline 1106 & 79 & M & 29 & Normal & II & $3 / 3$ & 44.1 \\
\hline 1309 & 83 & $\mathrm{~F}$ & 30 & Normal & II & $3 / 3$ & 0 \\
\hline 5415 & 86 & $\mathrm{~F}$ & 28 & Normal & III & $3 / 3$ & 0 \\
\hline 1087 & 82 & $\mathrm{~F}$ & 29 & Normal & III & $3 / 3$ & 0 \\
\hline 976 & 85 & $M$ & 30 & Normal & III & $3 / 3$ & 0 \\
\hline 5368 & 96 & $\mathrm{~F}$ & 1 & Dementia & IV & $3 / 3$ & 0 \\
\hline 1105 & 84 & $\mathrm{~F}$ & 30 & Normal & IV & $3 / 3$ & 0 \\
\hline 1141 & 84 & $\mathrm{~F}$ & 29 & Normal & IV & $3 / 3$ & 0 \\
\hline 5384 & 87 & $M$ & 0 & Dementia & V & $3 / 3$ & 151.9 \\
\hline 5387 & 98 & $\mathrm{~F}$ & 22 & Dementia & V & $3 / 3$ & 206.4 \\
\hline 1318 & 100 & $M$ & 27 & Dementia & V & $3 / 3$ & 0 \\
\hline 1169 & 93 & $\mathrm{~F}$ & 24 & Dementia & V & $3 / 3$ & 0 \\
\hline 5372 & 94 & $M$ & 24 & MCI & V & $3 / 3$ & 113.1 \\
\hline 972 & 89 & $\mathrm{~F}$ & 1 & Dementia & VI & $3 / 3$ & 0 \\
\hline 1113 & 89 & $\mathrm{~F}$ & 14.5 & Dementia & VI & $3 / 3$ & 0 \\
\hline 1053 & 90 & $\mathrm{~F}$ & 22.5 & Dementia & VI & $3 / 3$ & 85.9 \\
\hline 1033 & 71 & $M$ & 18 & Dementia & VI & $3 / 3$ & 0 \\
\hline 5389 & 92 & $M$ & 15 & Dementia & VI & $3 / 3$ & 152.4 \\
\hline 1096 & 84 & $M$ & 23 & Dementia & VI & $3 / 3$ & 151.4 \\
\hline 5396 & 90 & $\mathrm{~F}$ & $\mathrm{~N} / \mathrm{A}$ & Dementia & III & $2 / 4$ & 0 \\
\hline 965 & 82 & $\mathrm{~F}$ & 22 & Dementia & V & $2 / 4$ & 0 \\
\hline 1306 & 83 & $\mathrm{~F}$ & 30 & Normal & I & $3 / 4$ & 0 \\
\hline 1311 & 85 & $\mathrm{~F}$ & 30 & Normal & II & $3 / 4$ & 0 \\
\hline 5380 & 100 & $\mathrm{~F}$ & 21 & Dementia & V & $3 / 4$ & 116.4 \\
\hline 1035 & 84 & $\mathrm{~F}$ & 19 & Dementia & V & $3 / 4$ & 46.2 \\
\hline 1052 & 80 & $\mathrm{~F}$ & 19 & Dementia & VI & $3 / 4$ & 348.9 \\
\hline 1037 & 82 & $M$ & 17.5 & Dementia & VI & $3 / 4$ & 253.7 \\
\hline 5394 & 64 & $\mathrm{~F}$ & 6 & Dementia & VI & $3 / 4$ & 248.5 \\
\hline 1101 & 86 & $\mathrm{~F}$ & 7 & Dementia & VI & $3 / 4$ & 374.5 \\
\hline 5344 & 84 & $M$ & 2 & Dementia & VI & $3 / 4$ & 156.2 \\
\hline 5361 & 87 & $M$ & 13 & Dementia & V & $4 / 4$ & 59 \\
\hline 1182 & 71 & $\mathrm{~F}$ & 20 & Dementia & VI & $4 / 4$ & 0 \\
\hline 5335 & 62 & $\mathrm{~F}$ & 21 & Dementia & VI & $4 / 4$ & 0 \\
\hline
\end{tabular}

F, female; M, male; ApoE, Apolipoprotein E; MCI, mild cognitive impairment; MMSE, Mini-Mental State Examination; MS, mass spectrometry; NFT, neurofibrillary tangle.

ubiquitylation, and serine, threonine, and tyrosine phosphorylation. Mass error tolerance was set to be $<10 \mathrm{ppm}$ for MS and 0.8 Da for MS/MS. A decoy database was built and searched to determine the false discovery rates. Peptides with false discovery rates lower than 0.01 were assigned as high confidence identification. The MASCOT software returns probability-based scores, calculated from the spectra detected of the individual peptides. These are described in the manufacturer's manual for the Proteome Discoverer software. The protein scores, based on the scores of the identified peptides, were calculated by using Proteome Discoverer.
Further details on how the protein score is calculated are provided in the Proteome Discoverer Version 1.3 User Guide XCALI-97358 Revision A (available from the manufacturer). Only proteins with a score $\geq 30$ were included in the analysis in this study.

\section{Immunohistochemistry}

Immunohistochemical experiments were performed by using methods previously described, ${ }^{32,42}$ with slight modifications. Before immunohistochemistry, brain tissue was immersion-fixed in $10 \%$ neutral-buffered formalin 
Table 2 Association between Detected Protein Levels (Detergent-Insoluble Fraction) and Last Clinical Diagnosis in All Participants $(N=40)$

\begin{tabular}{|c|c|c|c|}
\hline \multirow[b]{2}{*}{ Protein } & \multicolumn{2}{|c|}{ Last clinical diagnosis, $n(\%)$} & \multirow[b]{2}{*}{$P$ value* } \\
\hline & Normal + MCI & Dementia & \\
\hline \multicolumn{4}{|l|}{ ApoE } \\
\hline Undetected $^{\dagger}$ & $15(93.8)$ & $9(37.5)$ & $6.71 \times 10^{-4}$ \\
\hline Detected & $1(6.2)$ & $15(62.5)$ & \\
\hline \multicolumn{4}{|l|}{ APP } \\
\hline Undetected $^{\dagger}$ & $10(62.5)$ & $5(20.8)$ & 0.018 \\
\hline Detected & $6(37.5)$ & $19(79.2)$ & \\
\hline \multicolumn{4}{|l|}{ MAPT } \\
\hline Undetected $^{\dagger}$ & $3(18.8)$ & $2(8.3)$ & 0.37 \\
\hline Detected & $13(81.2)$ & $22(91.7)$ & \\
\hline \multicolumn{4}{|l|}{ SNCA } \\
\hline Undetected $^{\dagger}$ & $16(100)$ & $13(54.2)$ & 0.0012 \\
\hline Detected & $0(0)$ & $11(45.8)$ & \\
\hline
\end{tabular}

* $P$ value was calculated by Fisher's exact test (undetected versus detected and normal + MCI versus dementia).

${ }^{\dagger}$ MASCOT score $<30$.

ApoE, Apolipoprotein E; MCI, mild cognitive impairment.

(catalog \#C4320-105; Cardinal Health, Dublin, $\mathrm{OH}$ ) for 2 to 4 weeks before paraffin embedding. Immunohistochemical stains were performed as previously described ${ }^{43}$ except that formic acid pretreatment was used for all slides. Briefly, sections cut at $8 \mu \mathrm{m}$ thickness from formalin-fixed, paraffin-embedded tissue blocks were deparaffinized before microwave antigen retrieval for 6 minutes (power 8) using citrate buffer (Declere buffer, Cell Marque, Rocklin, CA). The sections were then placed in $100 \%$ formic acid (catalog \#A-119P; Thermo Fisher Scientific) for 3 minutes. Sections were blocked in 5\% normal goat or rabbit serum in Tris-buffered saline (5\% S+TBS) for 1 hour at room temperature, then incubated in primary antibodies diluted in 5\% $\mathrm{S}+\mathrm{TBS}$, for 22 hours at $4^{\circ} \mathrm{C}$. Secondary antibodies were biotinylated IgG (catalog \#BA-1000, \#BA-2000, \#BA4000, and \#BA-5000; Vector Labs, Burlingame, CA) diluted at 1:200 in $5 \% \mathrm{~S}+\mathrm{TBS}$ for 1 hour at 19 to $22^{\circ} \mathrm{C}$. After washing, the Vectastain ABC kit (Vector Labs) was used with Vector NovaRED (Vector Labs), followed by counterstain with hematoxylin, rinsing, dehydration, clearing, and mounting in coverslip media.

For triple-label immunofluorescence, sections cut at $8 \mu \mathrm{m}$ thickness were deparaffinized before microwave antigen retrieval for 6 minutes (power 8) using citrate buffer (Declere buffer, Cell Marque). The sections were then placed in $100 \%$ formic acid for 3 minutes. Sections were next incubated for 45 seconds at room temperature in a $1 \times$ solution of TrueBlack (catalog \#23007; Biotium, Fremont, CA) prepared in $70 \%$ ethanol to reduce autofluorescence. Sections were blocked in 5\% normal donkey serum in TBS for 1 hour at room temperature, then incubated in primary antibodies anti-ApoE (rabbit monoclonal, 1:500 dilution; catalog \#ab52607; Abcam, Waltham, MA), anti-C4a (mouse monoclonal, 1:250 dilution, catalog \#ab187278; Abcam), and anti-Tau (goat polyclonal, 1:2500 dilution; catalog \#AF3496; R\&D Systems, Minneapolis, MN) diluted in 5\% normal donkey serum in TBS, for 48 hours at $4^{\circ} \mathrm{C}$. Secondary antibodies conjugated to Alexa Fluor probes 488, 568 (diluted 1:500, catalog \#A21206 and \#A10037; Life Technologies, Carlsbad, CA), and 647 (catalog \#A21447, Life Technologies), diluted 1:2500 in 5\% normal donkey serum in TBS for 1 hour at room temperature. Slides were cover-slipped by using Invitrogen ProLong Gold mounting medium with DAPI (catalog \#P36935; Thermo Fisher Scientific).

\section{Immunoblotting}

Proteins were resolved by denaturing SDS gel electrophoresis on 3\% to $8 \%$ TRIS-acetate gradient protein gels (catalog \#EA0378BOX; Thermo Fisher Scientific) using TRIS-acetate SDS running buffer (catalog \# LA0041; Thermo Fisher Scientific). The resolved proteins were transferred to nitrocellulose membranes (catalog \#1704158; Bio-Rad, Hercules, CA), followed by blocking with 5\% nonfat dry milk in TBST $(50 \mathrm{mmol} / \mathrm{L}$ Tris- $\mathrm{HCl}, 0.85 \%$ [w/v] NaCl, 0.1\% [v/v] Tween-20, pH 7.5). The primary and secondary antibodies were applied in blocking buffer. The secondary antibody was IRDye $800 \mathrm{CW}$ goat anti-rabbit IgG (catalog \#926-32211; Li-Cor, Lincoln, NE). The images were acquired on the Li-Cor Odyssey CLx Imaging System.

\section{Statistical Analysis}

Comparisons of detected ( $\geq 30$ MASCOT score) and undetected $(<30$ MASCOT score) proteins between subjects with dementia and normal people or people with mild cognitive impairment were performed with Fisher's exact

Table 3 Association between Detected Protein Levels (DetergentInsoluble Fraction) and Last Clinical Diagnosis in Participants without the APOE \&4 Allele $(n=26)$

\begin{tabular}{|c|c|c|c|}
\hline \multirow[b]{2}{*}{ Protein } & \multicolumn{2}{|c|}{ Last clinical diagnosis, $n(\%)$} & \multirow[b]{2}{*}{$P$ value ${ }^{*}$} \\
\hline & Normal + MCI & Demented & \\
\hline \multicolumn{4}{|l|}{ ApoE } \\
\hline Undetected $^{\dagger}$ & $13(92.9)$ & $5(41.7)$ & 0.0093 \\
\hline Detected & $1(7.1)$ & $7(58.3)$ & \\
\hline \multicolumn{4}{|l|}{ APP } \\
\hline Undetected $^{\dagger}$ & $8(57.1)$ & $5(41.7)$ & 0.69 \\
\hline Detected & $6(42.9)$ & $7(58.3)$ & \\
\hline \multicolumn{4}{|l|}{ MAPT } \\
\hline Undetected $^{\dagger}$ & $2(14.3)$ & $2(16.7)$ & 1 \\
\hline Detected & $12(85.7)$ & $10(83.3)$ & \\
\hline \multicolumn{4}{|l|}{ SNCA } \\
\hline Undetected $^{\dagger}$ & $14(100)$ & $6(50)$ & 0.0040 \\
\hline Detected & $0(0)$ & $6(50)$ & \\
\hline
\end{tabular}

${ }^{*} P$ value was calculated by Fisher's exact test [undetected versus detected and normal + MCI versus dementia].

${ }^{\dagger}$ MASCOT score $<30$.

ApoE, Apolipoprotein E; MCI, mild cognitive impairment. 


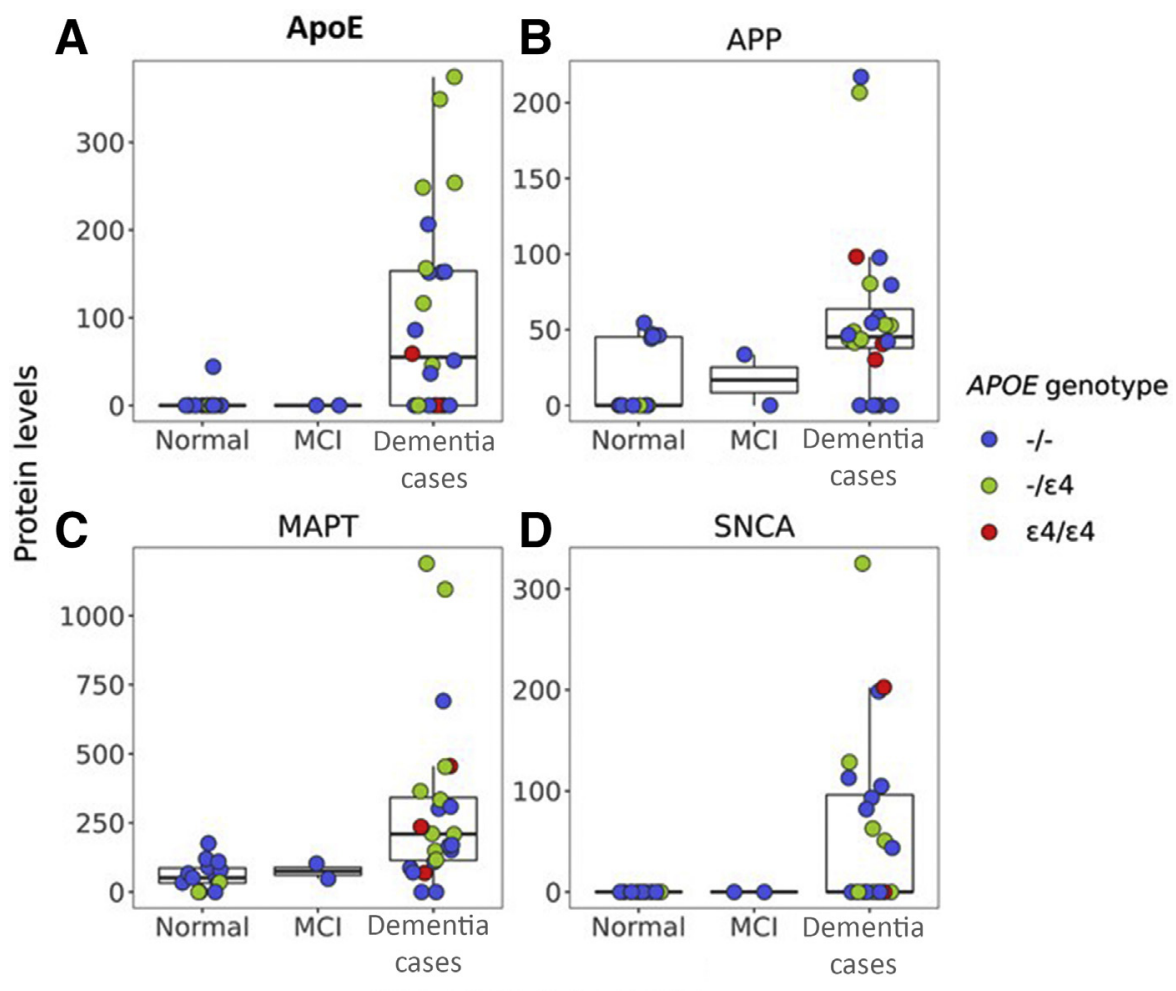

Last clinical diagnosis

Figure 2 Apolipoprotein $\mathrm{E}(\mathrm{ApoE})$ is enriched in the detergent-insoluble fraction of subjects with dementia, compared with other proteins, including in cases that lacked the APOE $\& 4$ allele. Shown are the results of proteins detected via mass spectrometry, stratified according to last clinical diagnosis. For comparison's sake, results are shown for ApoE (A), APP (B), MAPT/Tau (C), and SNCA/ $\alpha$-Synuclein (D). MCI, mild cognitive impairment.

tests. The multivariable Tweedie compound Poisson model was applied to handle zero-inflated continuous outcome by specifying a "Tweedie" distribution (from the "statmod" $\mathrm{R}$ package) in the generalized linear model framework. ${ }^{44}$ The "tweedie.profile" function from the "tweedie" R package was used to estimate the maximum likelihood estimation of the Tweedie power parameter with the range of 1 to 2 by 0.01 step. $^{45}$ The covariates included sex, age at death, and postmortem interval. All statistical analyses were conducted with $\mathrm{R}$ version 4.0.3 ( $\mathrm{R}$ Foundation for Statistical Computing, Vienna, Austria). Statistical significance was set at 0.05 .

\section{Results}

With the goal of identifying dementia-associated DIPPs in a relatively unbiased manner, the detergent-insoluble fractions of a set of amygdalae were analyzed, representing a spectrum of cognitive impairment before death. The study design and workflow are shown in Figure 1. Information on the biosamples used in LC-electrospray ionization-MS/MS experiments is presented in Table 1. After sequential processing with increasingly strong detergents, the proteinaceous pellets from amygdala samples were re-extracted with a solution that contained $7 \mathrm{~mol} / \mathrm{L}$ urea and $2 \mathrm{~mol} / \mathrm{L}$ thiourea, yielding the urea-soluble, "detergent-insoluble" fraction, the high-molecular weight portion of which was analyzed with mass spectrometry.

In total, $>800$ proteins with a MASCOT protein score of at least 30 were identified in at least one amygdala sample. A spreadsheet with all of the detected peptides, for all of the cases, is provided as Supplemental Table S1. The presence of the known DIPPs Tau, A $\beta$, and $\alpha$-Synuclein were confirmed in the amygdalae of patients with dementia. The co-incidence of the detection of these DIPPs with a MASCOT score of at least 30 was correlated with the last clinical diagnosis using Fisher's exact test. As expected, the detection of APP (A $\beta$ ) and SNCA ( $\alpha$-Synuclein) peptides in

Table 4 Associations between Proteins Levels and Dementia: Tweedie Generalized Linear Models (Outcome Is Protein Level, Predictor Is Last Clinical Diagnosis) in All Participants $(N=40)$ and among those without the APOE 84 Allele $(n=26)$

\begin{tabular}{llllll}
\hline & \multicolumn{2}{l}{$\begin{array}{l}\text { Including all subjects* } \\
\end{array}$} & & & \multicolumn{2}{l}{$\begin{array}{l}\text { Subjects lacking } A P O E \varepsilon 4^{*} \\
n=40\end{array}$} & & $n=26$ & \\
\cline { 2 - 3 } \cline { 5 - 6 } Protein & $\beta(\mathrm{SE})$ & $P$ value & & $\beta(\mathrm{SE})$ & $P$ value \\
\hline ApoE & $3.35(1.20)$ & 0.0085 & & $3.30(1.47)$ & 0.035 \\
APP & $1.20(0.46)$ & 0.013 & & $1.01(0.51)$ & 0.063 \\
MAPT & $1.21(0.40)$ & 0.0048 & & $1.01(0.30)$ & 0.0032 \\
\hline
\end{tabular}

*Adjusted for age at death, sex, and postmortem interval in hours. ApoE, Apolipoprotein E. 


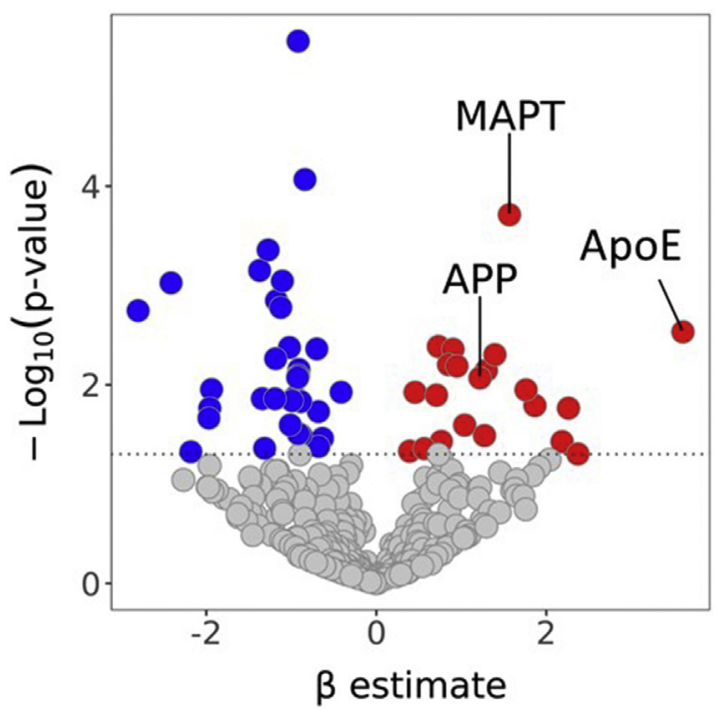

Figure 3 Apolipoprotein $\mathrm{E}(\mathrm{ApoE})$ protein is strongly enriched in the detergent-insoluble fraction of subjects with dementia detected via mass spectrometry, compared with other proteins. Proteins detected via mass spectrometry were assessed, comparing those with dementia versus nondemented subjects. A "volcano plot" is shown to depict the $P$ value ( $y$ axis, $\log _{10}$-transformed) and $\beta$ estimate ( $x$ axis) that conveys the size of the difference comparing the results of patients with dementia versus nondemented participants. Individual proteins that were up-regulated in the detergent-insoluble fraction of participants with dementia are shown in red, and those down-regulated are shown in blue. Because most of the proteins had undetected levels in most of the cases, the statistical analyses assessed continuous protein levels with a zero inflation (ie, it was assumed that each protein level follows a Tweedie distribution) among those proteins with $\geq 4$ people having undetected levels. The dotted line depicts the $P<0.05$ threshold for statistical significance.

the detergent-insoluble amygdala fractions correlated strongly with the clinical diagnosis of dementia (Table 2). For SNCA, the significant detection remained even in the subsample of participants who lacked the APOE $\varepsilon 4$ allele (Table 3). Tau and $A \beta$ proteins, but not $\alpha$-Synuclein, were occasionally detectable in the detergent-insoluble fraction of amygdalae from cognitively normal subjects and also patients diagnosed with mild cognitive impairment, albeit usually with lower MASCOT scores (Table 2 and Figure 2). Therefore, differences in the detected protein levels of Tau and $\mathrm{A} \beta$ between normal/mild cognitive impairment and cases of dementia were analyzed using the multivariable Tweedie compound Poisson model. People with dementia had significantly higher Tau and APP/A $\beta$ protein levels than the normal/mild cognitive impairment group (Table 4 and Figure 3). Overall, the findings for Tau, SNCA, and APP/ $\mathrm{A} \beta$ were in line with expectations of preclinical disease among elderly individuals ${ }^{46}$ (Table 1). However, it is also notable that a reliable signal for TDP-43-related peptides was not detected in the current study.

In addition to the widely recognized pathologic markers Tau, APP/A $\beta$, and $\alpha$-Synuclein, statistical analysis of the mass spectrometric data revealed a close correlation between dementia diagnosis and the detection of ApoE peptides in the detergent-insoluble fraction (Table 2, Figure 3, and Supplemental Figure S1). Overall, the correlation for ApoE peptides with dementia was even stronger than that seen for Tau, APP, or $\alpha$-Synuclein peptides. The $A P O E$ gene variation is well known for playing important roles in the susceptibility to developing AD. Stratification according to the $A P O E \varepsilon 4$ status suggested that the presence of $\varepsilon 4$ allele(s) led to high levels of insoluble ApoE in a subset of patients (Figure 2). Moreover, ApoE peptides were considerably enriched in the detergent-insoluble fraction of the amygdalae of patients with dementia even in the adjustment for (Table 4) and in the absence of (Tables 3 and 4) the $\varepsilon 4$ allele. These results indicate that ApoE insolubilization correlates closely with dementia and may be pathogenetically impactful even in cases that lack the $A P O E$ $\varepsilon 4$ allele.

Analysis of the tryptic peptides of ApoE identified with mass spectrometry in the detergent-insoluble amygdala fractions showed that they were clustered centrally, away from either the $\mathrm{N}$ - or C-terminal portions of the protein (Figure 4). Supplemental Table S2 presents all of the ApoE peptides detected across all cases. No phosphorylated serine, threonine or tyrosine, or acetylated or ubiquitinated lysine residue were identified in ApoE in the detergent-insoluble fractions.

To determine the distribution of ApoE solubility in the various protein extract fractions, immunoblotting was performed on the fractions from a cognitively normal control subject and a patient with dementia, both with APOE $\varepsilon 3 / 3$ genotypes. In both cases, ApoE was mostly detected in the LS and the Triton-X100 fractions, close to the expected processed monomeric molecular weight of $34.2 \mathrm{kDa}$

\begin{tabular}{rrrrr}
10 & 20 & 30 & 40 & 50 \\
MKVLWAALLV & TFLAGCQAKV & EQAVETEPEP & ELRQQTEWQS \\
60 & 70 & 80 & 90 & 100 \\
FWDYLRWVQT & LSEQVQEELL & SSQVTQELRA & IMDETMKELK & AYKSELEEQL \\
110 & 120 & 130 & 140 & 150 \\
TPVAEETRAR & LSKELQAAQA & RLGADMEDVC & GRLVQYRGEV & QAMLGQSTEE \\
160 & 170 & 180 & 190 & 200 \\
\hline LRVRLASHLR & KLRKRLLRDA & DDLQKRLAAVY & QAGAREGAER \\
\hline 210 & 220 & 230 & 240 & 250 \\
\hline PLVEQGRVRA & ATVGSLAGQP & LQERAQAWGE & RLRARMEEMG & SRTRDRLDEV \\
260 & 270 & 280 & 290 & 300 \\
\hline KEQVAEVRAK LEEQAQQIRL & QAEAFQARLK & SWFEPLVEDM & QRQWAGLVEK \\
310 & & &
\end{tabular}

Figure 4 Apolipoprotein E (ApoE) peptides identified via mass spectrometry from detergent-insoluble protein extracted from human amygdalae. The peptides identified with the highest confidence appeared to be clustered in the middle of the ApoE protein. Peptides from the $\mathrm{N}$ - and $\mathrm{C}$ termini were not detected in the detergent-insoluble fraction, suggesting that proteolytic trimming may have occurred in the aggregated ApoE species. The peptides with green highlight were detected at a high confidence level in at least one subject. The peptide with the red highlight was repeatedly detected only with low confidence. Labeled in the figure are rs429358 (a.a. 130; blue arrow) and rs7412 (a.a. 176; red arrow), which confer ApoE $\varepsilon$-isoform status, as well as several notable protein domains. Also shown with underlining are a.a. 154 to 168, LDR receptor binding domain (blue underline), and a.a. 262 to 290, lipid binding domain (red underline). 

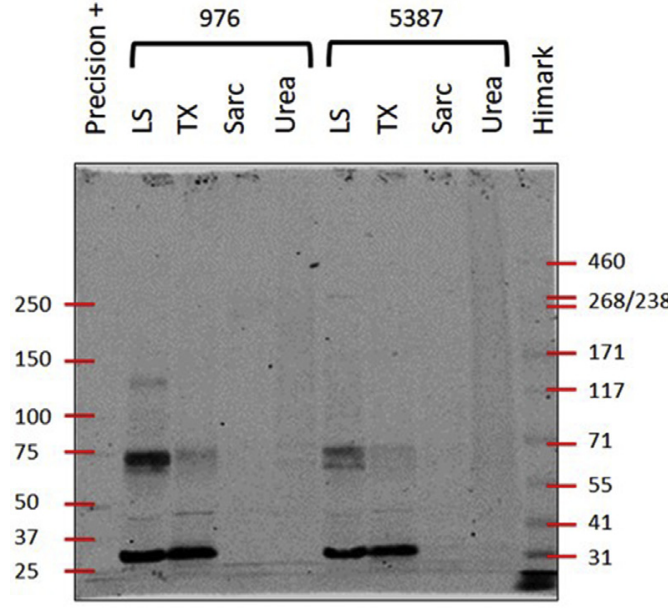

Anti-ApoE

Figure 5 Immunoblotting showing an enhanced Apolipoprotein $\mathrm{E}$ (ApoE) signal in the detergent-insoluble fraction of dementia patient amygdala. Amygdalae from a nondemented patient (Case 976) and a dementia patient (Case 5387), both with the APOE 3/3 genotype, were subjected to fractionation based on solubility, as described in the main text. The fractions were subjected to denaturing gel electrophoresis in the order of solubility with the low-salt ("LS") fraction being the most soluble, and the "urea" fraction (the detergent-insoluble fraction) the least soluble. Immunoblotting with an anti-ApoE antibody detected $\mathrm{ApoE}$ at the expected monomeric size, and also likely oligomeric forms, in the LS and TX [LS buffer supplemented with $1 \%(\mathrm{v} / \mathrm{v})$ Triton-X-100 and $0.5 \mathrm{~mol} / \mathrm{L} \mathrm{NaCl}]$ fractions. The detergent-insoluble fraction of patient 5387 with dementia contained enhanced ApoE signal in the form of a continuous smear.

(Figure 5). ApoE signal corresponding to likely multimers, primarily in the LS fractions, was also detected. The detergent-insoluble fraction of the patient with dementia had a continuous, smeared ApoE signal that was stronger, especially in the high molecular weight range, than in the control case. It is likely that this high molecular weight signal corresponded to the ApoE protein detected by using mass spectrometry.

Correlation analysis was performed to identify proteins in the detergent-insoluble high molecular weight fraction that were positively and negatively correlated with the ApoE peptides detected with mass spectrometry (Table 5 and Supplemental Figure S2). Strong correlations were found between levels of ApoE and a subset of proteins, including complement proteins $\mathrm{C} 3, \mathrm{C} 4 \mathrm{~A}$ and $\mathrm{C} 4 \mathrm{~B}$, Tau (MAPT), ubiquitin (represented by UBB, UBC, RPS27A, and UBA52), and the Collagen alpha-1(XXV) chain (COL25A1).

The histopathologic relationship between ApoE, C4, and Tau proteins was investigated using immunohistochemistry, focusing on brains from participants with the APOE $\varepsilon 3 / 3$ genotype. $\mathrm{C} 4$ was chosen as antigen out of convenience because of the availability of a robust antibody for immunohistochemistry (Table 6). Results of immunohistochemical staining of ApoE are depicted in Figures 6 to 8 and Table 7 . In a cognitively normal participant with the highest possible final Mini-Mental State Examination (MMSE) score $(\mathrm{MMSE}=30)$ and no ApoE detected by mass spectrometry (Panel A, Case 1309), ApoE was primarily detected in reactive astrocytes and capillary profiles. In the only cognitively normal control subject in our cohort (MMSE = 29) with ApoE detected in the detergentinsoluble fraction (Case 1106), the ApoE staining of microglia and astrocytes was less pronounced. Instead, structures with the histomorphologic appearance of diffuse amyloid plaques were apparent (Figure 6B). In an individual who died with dementia (Case 1068; MMSE = 22.5), multiple stained structures, including astrocytes, blood vessels, and amyloid plaques, were apparent (Figure 6C). ApoE immunohistochemistry staining was performed on additional amygdalae from 11 patients with dementia (MMSE $\leq 24$ ) with $A P O E \varepsilon 2 / 3,3 / 3$, and 3/4 genotypes. Our findings showing extensive AD-type pathology in patients with dementia are summarized in Table 7 . In a post hoc convenience sample of APOE $\varepsilon 3 / 3$ cases $(n=5)$ that were not among the subjects sampled for proteomics studies, the same general findings were observed: in cases lacking $\mathrm{AD}$ pathology, ApoE immunohistochemistry predominantly labeled astrocytes, whereas in cases with AD pathology, ApoE immunohistochemistry labeled amyloid plaques and some cells that looked like neurofibrillary tangles (Supplemental Table S3 and Supplemental Figure S3).

As indicated by immunofluorescence microscopy, the ApoE and C4 proteins were co-localized extensively in senile plaque-like structures (Figure 7). Some areas showed more ApoE immunohistochemical signal, particularly small blood vessels, in areas lacking AD-type plaques and tangles. Particular microdomains of amyloid plaques were more strongly stained for $\mathrm{C} 4$ than for ApoE. The Tau protein was immunolocalized, as expected, in neurofibrillary tangles, neuritic threads, and neuritic plaques, and, although nearby,

Table 5 ApoE Peptides Detected in Detergent-Insoluble Fraction According to Mass Spectrometry Data: Correlations $\left(r^{2}\right)$ with Other Proteins (Top 15) Across All Included Participants $(N=40)$

\begin{tabular}{llll}
\hline \multicolumn{2}{l}{ Positive correlations } & \multicolumn{2}{l}{ Negative correlations } \\
\hline C3 & 0.889885 & EPB41L3 & -0.50981 \\
MAPT & 0.794382 & CAMK2B & -0.45293 \\
UBB & 0.761242 & CAMK2D & -0.42138 \\
COL25A1 & 0.741231 & CAMK2A & -0.40312 \\
C4A & 0.600414 & NEFL & -0.3862 \\
C4B & 0.598196 & IQSEC1 & -0.37179 \\
TRAF3IP1 & 0.565691 & EPB41L1 & -0.36325 \\
PTGDS & 0.560328 & IQSEC2 & -0.36027 \\
CLU & 0.53809 & NEFM & -0.35971 \\
PSAP & 0.525282 & INA & -0.35919 \\
PAK3 & 0.498618 & CAMKV & -0.35605 \\
PAK1 & 0.498618 & DNM3 & -0.35087 \\
CTSD & 0.493292 & TUBA4B & -0.34833 \\
SNCA & 0.492116 & GNAI2 & -0.33298 \\
OLFM2 & 0.472014 & GNA12 & -0.33213 \\
\hline
\end{tabular}

ApoE, Apolipoprotein E. 
Table 6 Antibodies and Antisera Used in the Current Study

\begin{tabular}{lllll}
\hline Antigen & Vendor & Catalog \# & Epitope/antigen & Uses in current study \\
\hline ApoE & Abcam & Ab52607 & "Near C-Terminal" & WB, IHC-P/IF \\
C4a & Abcam & Ab187278 & Full length protein & IHC-P/IF \\
Tau & R\&D Systems & AF3494 & Residues Gln624-Gln756 & IHC-P/IF \\
\hline
\end{tabular}

ApoE, Apolipoprotein E; IF, immunofluorescence; IHC-P, immunohistochemistry-paraffin embedded tissues; WB, Western blot.

the Tau protein did not co-localize specifically with ApoE or C4 proteins in amyloid plaques. A high-magnification image of a plaque-like structure in the brain of Case 1068 shows strong ApoE signal in the plaque core, whereas the C4 signal was also strong in the periphery of the plaque (Figure 8). The Tau-immunoreactive structures were often nearby but outside the ApoE or $\mathrm{C} 4$ signal. The ApoE antibody also highlighted small vessels and glial profiles that were not immunolabeled by the $\mathrm{C} 4$ antibody.

\section{Discussion}

The ApoE protein was robustly detected in detergentinsoluble amygdala extracts via mass spectrometry in dementia brains, from research participants with or without the $A P O E \& 4$ genotype. The study goals initially were not focused on ApoE; rather, the study was designed to identify and characterize novel DIPPs relevant to NDs. With this aim, proteins from samples of human amygdalae were extracted and analyzed with LC-electrospray ionization-MS/ MS. Polypeptides present in detergent-insoluble extracts of patients with antemortem cognitive impairment were queried and compared with those in control brains. Relative to other proteins identifiable in the mass spectrometry data, including the signals referent to established DIPPs such as Tau, A $\beta$, and $\alpha$-Synuclein, the ApoE results stood out. The strength of signal from the ApoE in the detergent-insoluble fraction was also positively correlated with the presence of complement proteins, particularly C3, C4A, and C4B.

There have been previous analyses of the human amygdala proteome. ${ }^{47-49}$ However, no studies have reported on the amygdala proteome in a sample of this size with dementia subjects and control subjects for the sake of comparison. Other prior studies examined DIPP preparations from human brain samples outside of the amygdala, including mass spectrometric analyses of brain extracts from subjects with dementia-associated pathologies such as AD, limbic-predominant age-related TDP-43 encephalopathy neuropathologic change, and frontotemporal lobar degeneration. ${ }^{8,50-54}$

The full-length ApoE protein includes an N-terminal signal peptide (Met1-Ala18) that is removed upon sorting. ${ }^{55}$ No ApoE peptide was identified in the current study before the Ala80 residue. The ApoE region between Ala80 and Ala255 comprises eight 22-residue tandem repeats, in which the majority of the identified peptides were clustered. The C-terminal segment of the ApoE protein (residues Leu279 to His317) was not represented by identified peptides either. This C-terminal region is responsible for lipid binding, lipoprotein association, and oligomerization. ${ }^{56-58}$ Importantly, aggregation-prone regions were previously identified in the central region of ApoE. ${ }^{59}$

The $A P O E \& 4$ allele has been associated clinically with increased dementia risk and pathologically with increased A $\beta$ plaque load. ${ }^{16,60-65}$ Our results emphasized the relevance of the ApoE protein as a particularly important protein aggregate constituent in itself and not only as an "upstream" genetic risk factor. These results may indicate

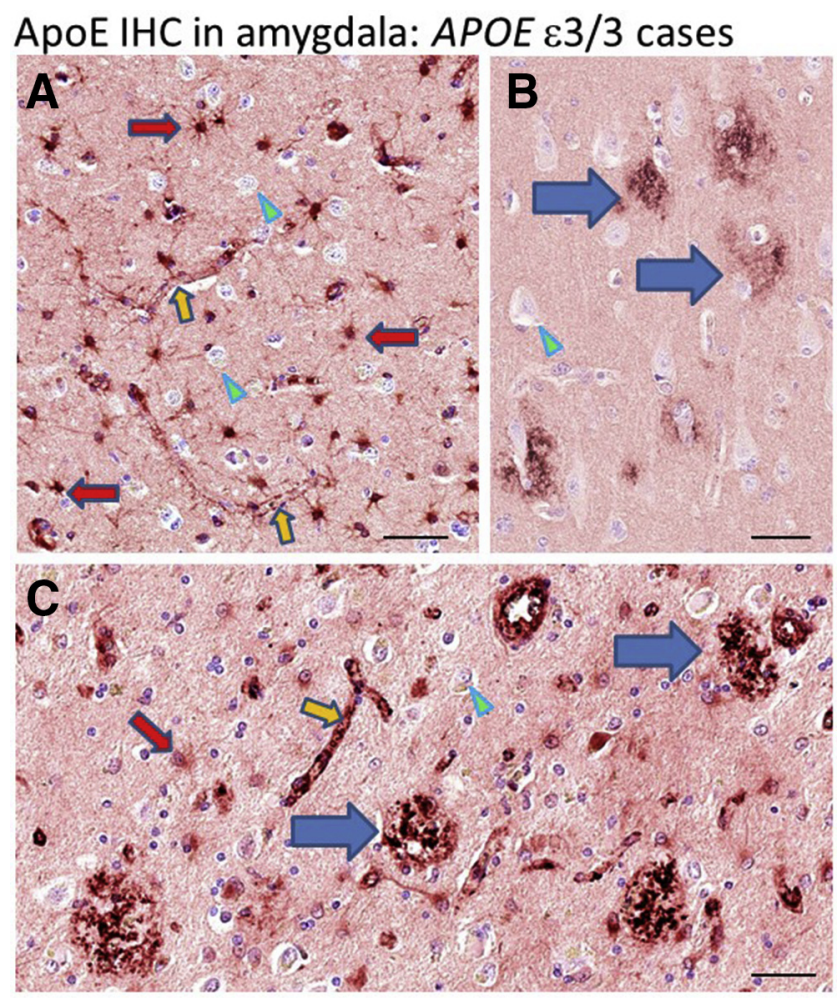

Figure 6 Brightfield immunohistochemical (IHC) staining of Apolipoprotein $\mathrm{E}(\mathrm{ApoE})$ in amygdala, from cases with the $A P O E \varepsilon 3 / 3$ genotype. The antibody used here is the same as the one used in the immunoblot in Figure 5. Cells with histologic features of neurons are shown with pale blue arrowheads in Panels A-C. Panel A shows ApoE structures in the amygdala of Case 1309, a nondemented participant. Note the reactive astrocytes (red arrows) and the capillary profiles (orange arrows). Panel B shows structures with the histomorphologic appearance of diffuse amyloid plaques (blue arrows) (Case 1106, a nondemented participant). In the photomicrograph in Panel C (dementia Case 1068) are multiple stained structures, including astrocytes (red arrow), blood vessels (orange arrow), and amyloid plaques (blue arrows). Scale bars: $60 \mu \mathrm{m}$ (A); $40 \mu \mathrm{m}$ (B); $50 \mu \mathrm{m}$ (C). 

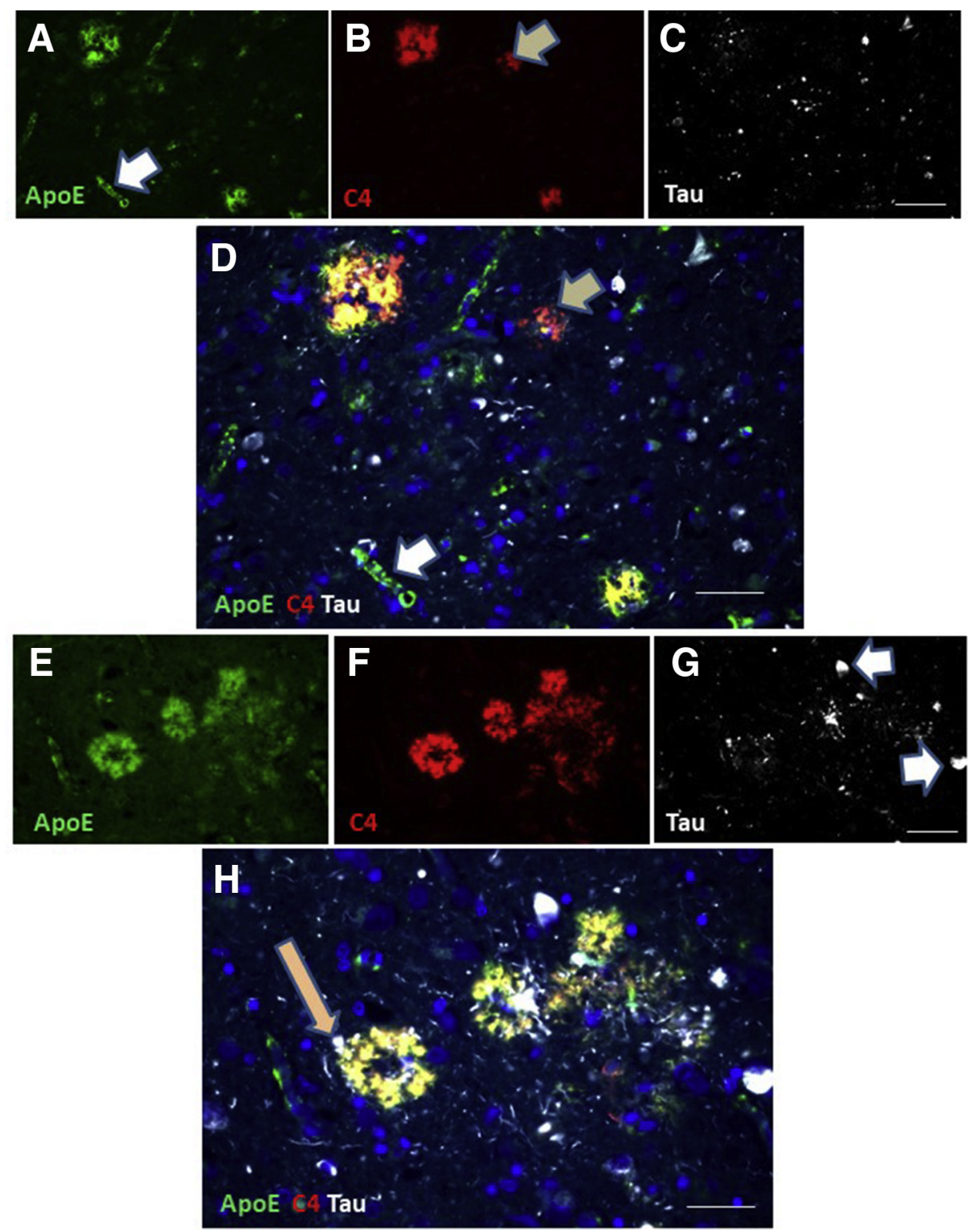

Figure 7 Immunofluorescence microscopy showing the localization of Apolipoprotein E (ApoE) (green; A and E), C4 (red; B and F), and Tau (white; C and G) proteins in two different brains with the $A P O E \varepsilon 3 / 3$ genotype. Panels $\mathbf{D}$ and $\mathbf{H}$ show the photomicrographs with the signals merged, with yellow indicating signal overlap. These photomicrographs are from amygdala sections from dementia Case 1068 (A-D) and dementia Case 1096 (E-H). Although the ApoE and C4 signals co-localized extensively, some areas show more ApoE, particularly small blood vessels (white arrow in panels $\mathbf{A}$ and $\mathbf{D}$ ). Some regions of plaques were more strongly stained for $\mathrm{C} 4$ than for ApoE (beige arrow in panels $\mathbf{B}$ and $\mathbf{D}$ ). Tau protein was seen, as expected in neurofibrillary tangles (white arrows in panel $\mathbf{G}$ ) and neuritic threads and neuritic plaques (beige arrow in Panel $\mathbf{H}$ ), and did not co-localize substantially with ApoE or C4. Scale bars: $\mathbf{C}$ (for $\mathbf{A}-\mathbf{C}$ ), 50 $\mu \mathrm{m} ; \mathbf{D}, 70 \mu \mathrm{m} ; \mathbf{G}$ (for $\mathbf{E}-\mathbf{G}), 50 \mu \mathrm{m} ; \mathbf{H}, 70 \mu \mathrm{m}$.

prevalent phenomena, particularly because this convenience sample was drawn from a community-based clinical cohort.

Although the current study design was unique, the key findings are compatible with (and confirmatory of) data reported in prior studies from other laboratories. The focus on human studies highlights three points that were previously described in various cohorts and contexts. First, ApoE was found to be aberrantly aggregated in dementia brains, and several potentially pathogenetic fragments of ApoE have been implicated. Second, immunohistochemical stains showed ApoE protein to be co-localized with both amyloid plaques and Tau tangles in $\mathrm{AD}$ brains, including in $A P O E$ $\varepsilon 3 / 3$ cases. Third, ApoE has been proposed to play roles in modulating brains' neuroinflammatory signaling.

Consistent with the findings in the current study, ApoE protein was previously shown to be aberrantly deposited in dementia brains, and proteolytic cleavage fragments of the protein were identified that may be neurotoxic. The ApoE 

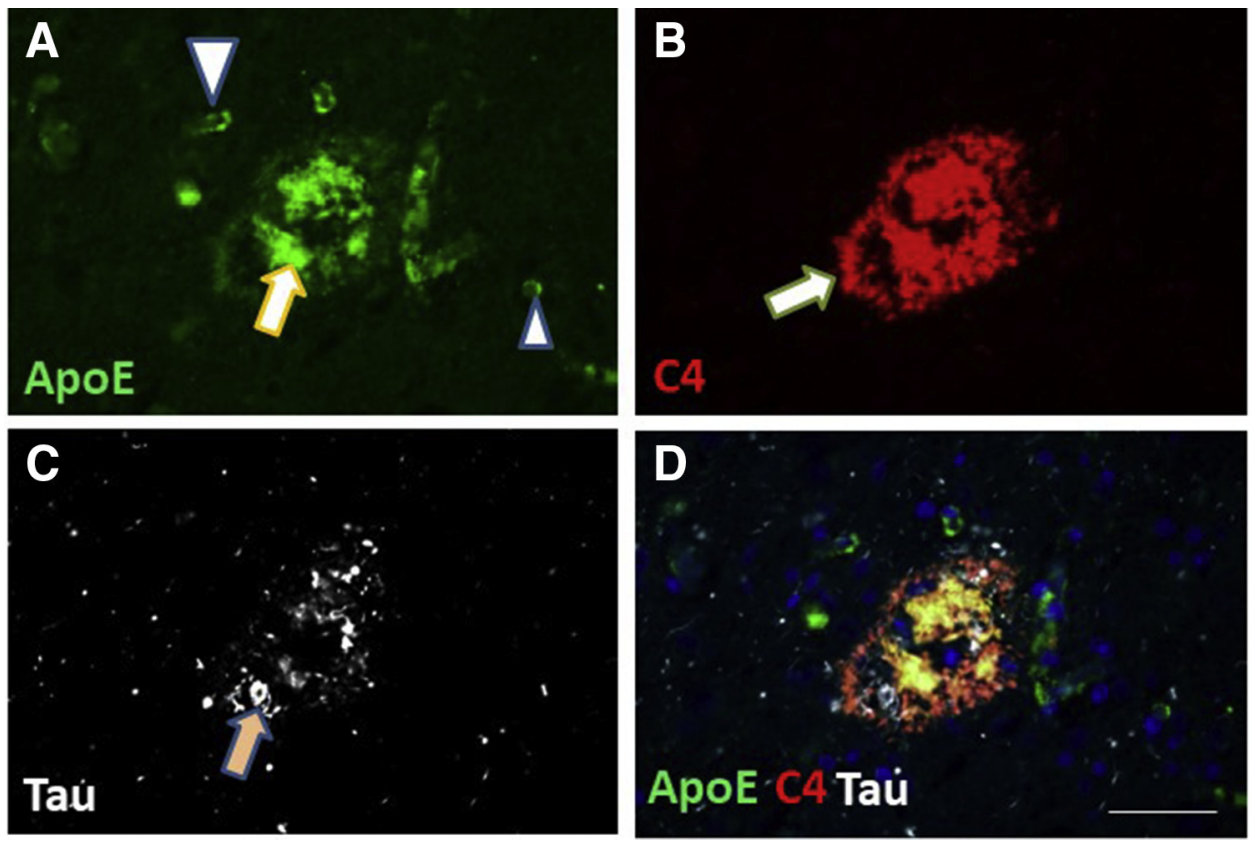

Figure 8 Immunofluorescence microscopy showing a single neuritic amyloid plaque with the localization of Apolipoprotein E (ApoE) (green; A), C4 (red; B), and Tau (white; C) proteins in amygdala of a person with the $A P O E \varepsilon 3 / 3$ genotype (Case 1068). In the depicted plaque-like structure, the ApoE signal is strongest in the plaque core (arrow in panel A), whereas the C4 signal is also strong in the periphery (arrow in panel B). The Tau-immunoreactive structures are often outside the ApoE or C4 signal (arrow in panel C). Panel $\mathbf{D}$ shows all three colors, and yellow depicts green-red regions of overlap. The ApoE antibody labels small vessels (large arrowhead in panel $\mathbf{A}$ ) and glial profiles (smaller arrowhead in panel A) that are not labeled by the C 4 antibody. Scale bar $=50$ $\mu \mathrm{m}$.

protein was enriched in subjects with dementia in prior analyses of proteomes (particularly the detergent-insoluble fractions) of human brains. ${ }^{51,53,66-70}$ An N-terminal ApoE cleavage product was characterized in $\mathrm{AD}$ and Down syndrome brains, and co-localized via immunohistochemistry in Tau tangles. ${ }^{71-75}$ Extensive work has focused on how that $\mathrm{N}$-terminal ApoE fragment may be neurotoxic and may participate in the $\mathrm{AD}$ pathogenesis mechanism(s). ${ }^{72,76,77} \mathrm{By}$ contrast, when $\mathrm{A} \beta$ peptide was isolated from $\mathrm{AD}$ brains, it was bound to a $\mathrm{C}$-terminal cleavage product of ApoE. ${ }^{78,79}$

Table 7 Immunohistochemical Staining for ApoE in Amygdala Sections from a Convenience Sample of 14 Cases from the University of Kentucky AD Research Center Biobank

\begin{tabular}{|c|c|c|c|c|c|c|c|c|c|}
\hline Case \# & Age, years & Sex & $\begin{array}{l}\text { Final } \\
\text { MMSE } \\
\text { score }\end{array}$ & $\begin{array}{l}\text { Braak NFT } \\
\text { stage }\end{array}$ & $\begin{array}{l}\text { CERAD neuritic } \\
\text { amyloid plaque } \\
\text { severity }\end{array}$ & $\begin{array}{l}A P O E \\
\text { allele } \\
\text { status }\end{array}$ & $\begin{array}{l}\text { ApoE MS } \\
\text { result }\end{array}$ & $\begin{array}{l}\text { ApoE stained } \\
\text { astrocytes* }\end{array}$ & $\begin{array}{l}\text { ApoE IHC-stained } \\
\text { AD-type pathology }\end{array}$ \\
\hline 1068 & 92 & $F$ & 22.5 & VI & Moderate & $2 / 3$ & 51.1 & + & + \\
\hline 1298 & 96 & $\mathrm{~F}$ & 24 & VI & Severe & $2 / 3$ & 36.4 & ++ & ++ \\
\hline 5384 & 87 & $M$ & 0 & V & Moderate & $3 / 3$ & 151.9 & ++ & + \\
\hline 1096 & 84 & M & 23 & VI & Severe & $3 / 3$ & 151.4 & ++ & ++ \\
\hline 1053 & 90 & $\mathrm{~F}$ & 22.5 & VI & Severe & $3 / 3$ & 85.9 & ++ & ++ \\
\hline 5372 & 94 & $M$ & 24 & V & Severe & $3 / 3$ & 113.1 & ++ & ++ \\
\hline 5394 & 64 & $\mathrm{~F}$ & 6 & VI & Severe & $3 / 4$ & 248.5 & + & +++ \\
\hline 1101 & 86 & $\mathrm{~F}$ & 7 & VI & Severe & $3 / 4$ & 374.5 & + & ++ \\
\hline 1052 & 80 & $F$ & 19 & VI & Moderate & $3 / 4$ & 348.9 & + & +++ \\
\hline 1035 & 84 & $\mathrm{~F}$ & 19 & V & Severe & $3 / 4$ & 46.2 & + & +++ \\
\hline
\end{tabular}

*ApoE IHC staining of cells resembling reactive astrocytes in amygdala: minimal $(+)$, moderate $(++)$, and widespread $(+++)$.

${ }^{\dagger} A D$ neuropathologic change features stained with ApoE IHC in amygdala: none $(-)$; a minimal number of focal senile plaque-like structures $(+)$, moderate densities of senile-plaque-like structures $(++)$, or widespread senile plaques with some structures that resemble NFTs $(+++)$.

F, female; M, male; AD, Alzheimer disease; ApoE, Apolipoprotein E; IHC, immunohistochemistry; MCI, mild cognitive impairment; MMSE, Mini-Mental State Examination; MS, mass spectrometry; NFT, neurofibrillary tangle. 
Despite these observations, there is no widespread awareness of the potential for misfolded and/or cleaved ApoE in the brain to be strongly relevant to $A P O E \varepsilon 4$ noncarriers.

Previous studies have used immunohistochemical stains in human brain to show that ApoE protein is co-localized with both amyloid plaques and Tau neurofibrillary tangles, including in some Down syndrome and $A P O E$ E3/3 cases. $^{73,74,80-87}$ Although $A P O E$ is preferentially transcribed in astrocytes and microglia, ${ }^{88,89}$ the ApoE protein also exists in neurons according to immunohistochemical stains. ${ }^{81}$ The intraneuronal ApoE was present in control subjects and $\mathrm{AD}$, not only co-localized with tangles. ${ }^{90} \mathrm{ApoE}$ deposition has also been linked to vascular disease, including cerebral amyloid angiopathy. ${ }^{80,83,91-93}$ It has been hypothesized that ApoE deposition is an early event often preceding the presence of $\mathrm{N}$-terminal epitopes of $\mathrm{A} \beta$ in the evolving plaque morphology in amyloid plaques, ${ }^{92}$ providing a scaffolding for ensuing protein deposition. ${ }^{94}$ The presence of ApoE in amyloid plaques was associated with dystrophic neurites. ${ }^{95}$ However, not all amyloid plaques with dystrophic neurites are immunopositive for ApoE. ${ }^{96}$ According to Cho et al, ${ }^{97}$ "Double-labeling demonstrated that the plaque cores contained the entire ApoE protein, but that outer regions contained only a Cterminal fragment, suggesting a cleavage in the random coil region of ApoE." Together, these findings point to intriguing connections between ApoE proteolytic cleavage and the development and toxicity of the microscopic markers of AD. However, there was no evidence of either extreme $\mathrm{N}$ - or $\mathrm{C}$-terminal peptides in the detergent-insoluble proteome in the current study.

In addition to being aberrantly aggregated and/or cleaved in $\mathrm{AD}$ brains, and its presence in the disease-defining microscopic lesions of $\mathrm{AD}, \mathrm{ApoE}$ has also been implicated in modifying neuroinflammatory signals. ${ }^{18}$ In the current study, C3 and C4 proteins were strongly associated with ApoE in the detergent-insoluble proteome detected with mass spectrometry. This correlation was robust in $A P O E$ \&4 noncarriers, and immunohistochemical studies confirmed that ApoE and $\mathrm{C} 4 \mathrm{a}$ co-localized in both plaques and tangles, including in APOE $\varepsilon 3 / 3$ participants' brains. ApoE was previously shown to be associated with complement protein, particularly in cerebrospinal fluid. ${ }^{98-100}$ The exact implications of these correlations are unknown, but they indicate the existence of interactions between ApoE and complement activation that may be targetable for potential disease modification.

There are limitations and caveats that apply to the current study. Although established pathologic markers are commonly identifiable in the amygdala at autopsy of older persons, it only represents a specific subset of the findings related to dementia. Additional limitations of the current study include the relatively small sample sizes, intrinsic imperfections in the proteomic analyses that do not include all peptides due to various biochemical factors, and the potential pitfalls of false-negative and false-positive results when undertaking follow-up studies with commercially available antibodies. Furthermore, all the samples used in the current study were from a single center. Although this reduces the likelihood of handling differences, there is a possibility that these results may not be generalizable. We note that there were a number of different proteins (ie, other than ApoE, Tau) that showed evidence of enrichment in the detergent-insoluble proteome, and we will be investigating these proteins in future studies.

Although the aforementioned caveats deserve consideration, the current study adds to an evolving appreciation of multiple misfolded proteins in the human brain. There is general agreement that there are four prevalently deposited/ misfolded polypeptide species that are strongly associated with the dementia phenotype: $\mathrm{A} \beta$, Tau, $\alpha$-Synuclein, and TDP-43. ApoE not only deserves to be considered a fifth member of this group, but, even in persons lacking the APOE \&4 allele, ApoE may indeed be among the most impactful misfolded proteins in aging brains.

\section{Acknowledgment}

We thank the research volunteers and clinical colleagues at the University of Kentucky Alzheimer's Disease Research Center.

\section{Supplemental Data}

Supplemental material for this article can be found at http://doi.org/10.1016/j.ajpath.2021.11.013.

\section{References}

1. Rahimi J, Kovacs GG: Prevalence of mixed pathologies in the aging brain. Alzheimers Res Ther 2014, 6:82

2. Karanth S, Nelson PT, Katsumata Y, Kryscio RJ, Schmitt FA, Fardo DW, Cykowski MD, Jicha GA, Van Eldik LJ, Abner EL: Prevalence and clinical phenotype of quadruple misfolded proteins in older adults. JAMA Neurol 2020, 77:1299-1307

3. Kapasi A, DeCarli C, Schneider JA: Impact of multiple pathologies on the threshold for clinically overt dementia. Acta Neuropathol 2017, 134:171-186

4. Wolozin BL, Pruchnicki A, Dickson DW, Davies P: A neuronal antigen in the brains of Alzheimer patients. Science 1986, 232:648-650

5. Neumann M, Sampathu DM, Kwong LK, Truax AC, Micsenyi MC, Chou TT, Bruce J, Schuck T, Grossman M, Clark CM, McCluskey LF, Miller BL, Masliah E, Mackenzie IR, Feldman H, Feiden W, Kretzschmar HA, Trojanowski JQ, Lee VM-Y: Ubiquitinated TDP-43 in frontotemporal lobar degeneration and amyotrophic lateral sclerosis. Science 2006, 314:130-133

6. Glenner GG, Wong CW: Alzheimer's disease: initial report of the purification and characterization of a novel cerebrovascular amyloid protein. Biochem Biophys Res Commun 1984, 120:885-890

7. Drummond E, Pires G, MacMurray C, Askenazi M, Nayak S, Bourdon M, Safar J, Ueberheide B, Wisniewski T: Phosphorylated tau interactome in the human Alzheimer's disease brain. Brain 2020, $143: 2803-2817$

8. Hales CM, Dammer EB, Deng Q, Duong DM, Gearing M, Troncoso JC, Thambisetty M, Lah JJ, Shulman JM, Levey AI, 
Seyfried NT: Changes in the detergent-insoluble brain proteome linked to amyloid and tau in Alzheimer's disease progression. Proteomics 2016, 16:3042-3053

9. Ping L, Kundinger SR, Duong DM, Yin L, Gearing M, Lah JJ, Levey AI, Seyfried NT: Global quantitative analysis of the human brain proteome and phosphoproteome in Alzheimer's disease. Sci Data 2020, 7:315

10. Shang J, Zrazhevskiy P, Postupna N, Keene CD, Montine TJ, Gao X: Multiplexed in-cell immunoassay for same-sample protein expression profiling. Sci Rep 2015, 5:13651

11. Bu G: Apolipoprotein E and its receptors in Alzheimer's disease: pathways, pathogenesis and therapy. Nat Rev Neurosci 2009, 10: 333-344

12. Nelson PT, Dickson DW, Trojanowski JQ, Jack CR, Boyle PA, Arfanakis K, et al: Limbic-predominant age-related TDP-43 encephalopathy (LATE): consensus working group report. Brain 2019 , 142:1503-1527

13. Farfel JM, Yu L, Buchman AS, Schneider JA, De Jager PL, Bennett DA: Relation of genomic variants for Alzheimer disease dementia to common neuropathologies. Neurology 2016, 87: 489-496

14. Jicha GA, Parisi JE, Dickson DW, Cha RH, Johnson KA, Smith GE, Boeve BF, Petersen RC, Knopman DS: Age and apoE associations with complex pathologic features in Alzheimer's disease. J Neurol Sci 2008, 273:34-39

15. Saunders AM, Strittmatter WJ, Schmechel D, George-Hyslop PH, Pericak-Vance MA, Joo SH: Association of apolipoprotein E allele epsilon 4 with late-onset familial and sporadic Alzheimer's disease. Neurology 1993, 43:1467-1472

16. Corder EH, Saunders AM, Strittmatter WJ, Schmechel DE, Gaskell PC, Small GW, Roses AD, Haines JL, Pericak-Vance MA: Gene dose of apolipoprotein E type 4 allele and the risk of Alzheimer's disease in late onset families. Science 1993, 261:921-923

17. Belloy ME, Napolioni V, Greicius MD: A quarter century of APOE and Alzheimer's disease: progress to date and the path forward. Neuron 2019, 101:820-838

18. Kloske CM, Wilcock DM: The important interface between apolipoprotein E and neuroinflammation in Alzheimer's disease. Front Immunol 2020, 11:754

19. Rebeck GW: The role of APOE on lipid homeostasis and inflammation in normal brains. J Lipid Res 2017, 58:1493-1499

20. Abondio P, Sazzini M, Garagnani P, Boattini A, Monti D, Franceschi C, Luiselli D, Giuliani C: The genetic variability of APOE in different human populations and its implications for longevity. Genes (Basel) 2019, 10:222

21. Braak H, Thal DR, Ghebremedhin E, Del Tredici K: Stages of the pathologic process in Alzheimer disease: age categories from 1 to 100 years. J Neuropathol Exp Neurol 2011, 70:960-969

22. Neltner JH, Abner EL, Jicha GA, Schmitt FA, Patel E, Poon LW, Marla G, Green RC, Davey A, Johnson MA, Jazwinski SM, Kim S, Davis D, Woodard JL, Kryscio RJ, Van Eldik LJ, Nelson PT: Brain pathologies in extreme old age. Neurobiol Aging 2016, 37:1-11

23. Scott SA, DeKosky ST, Scheff SW: Volumetric atrophy of the amygdala in Alzheimer's disease: quantitative serial reconstruction. Neurology 1991, 41:351-356

24. Scott SA, DeKosky ST, Sparks DL, Knox CA, Scheff SW: Amygdala cell loss and atrophy in Alzheimer's disease. Ann Neurol 1992, 32: $555-563$

25. Kromer Vogt LJ, Hyman BT, Van Hoesen GW, Damasio AR: Pathological alterations in the amygdala in Alzheimer's disease. Neuroscience 1990, 37:377-385

26. Tsuchiya K, Kosaka K: Neuropathological study of the amygdala in presenile Alzheimer's disease. J Neurol Sci 1990, 100:165-173

27. Unger JW, Lapham LW, McNeill TH, Eskin TA, Hamill RW: The amygdala in Alzheimer's disease: neuropathology and Alz 50 immunoreactivity. Neurobiol Aging 1991, 12:389-399
28. Braak H, Braak E, Yilmazer D, de Vos RA, Jansen EN, Bohl J, Jellinger K: Amygdala pathology in Parkinson's disease. Acta Neuropathol 1994, 88:493-500

29. Nelson PT, Abner EL, Patel E, Anderson S, Wilcock DM, Kryscio RJ, Van Eldik LJ, Jicha GA, Gal Z, Nelson RS, Nelson BG, Gal J, Azam MT, Fardo DW, Cykowski MD: The amygdala as a locus of pathologic misfolding in neurodegenerative diseases. J Neuropathol Exp Neurol 2018, 77:2-20

30. Josephs KA, Murray ME, Whitwell JL, Tosakulwong N, Weigand SD, Petrucelli L, Liesinger AM, Petersen RC, Parisi JE, Dickson DW: Updated TDP-43 in Alzheimer's disease staging scheme. Acta Neuropathol 2016, 131:571-585

31. Nelson PT, Trojanowski JQ, Abner EL, Al-Janabi OM, Jicha GA, Schmitt FA, Smith CD, Fardo DW, Wang W-X, Kryscio RJ, Neltner JH, Kukull WA, Cykowski MD, Van Eldik LJ, Ighodaro ET: "New old pathologies": AD, PART, and cerebral age-related TDP-43 with sclerosis (CARTS). J Neuropathol Exp Neurol 2016, 75: 482-498

32. Gal J, Chen J, Katsumata Y, Fardo DW, Wang W-X, Artiushin S, Price D, Anderson S, Patel E, Zhu H, Nelson PT: Detergent insoluble proteins and inclusion body-like structures immunoreactive for PRKDC/DNA-PK/DNA-PKcs, FTL, NNT, and AIFM1 in the amygdala of cognitively impaired elderly persons. J Neuropathol Exp Neurol 2018, 77:21-39

33. Schmitt FA, Wetherby MM, Wekstein DR, Dearth CM, Markesbery WR: Brain donation in normal aging: procedures, motivations, and donor characteristics from the Biologically Resilient Adults in Neurological Studies (BRAiNS) project. Gerontologist 2001, 41:716-722

34. Nelson PT, Jicha GA, Schmitt FA, Liu H, Davis DG, Mendiondo MS, Abner EL, Markesbery WR: Clinicopathologic correlations in a large Alzheimer disease center autopsy cohort: neuritic plaques and neurofibrillary tangles "do count" when staging disease severity. J Neuropathol Exp Neurol 2007, 66:1136-1146

35. Davis DG, Schmitt FA, Wekstein DR, Markesbery WR: Alzheimer neuropathologic alterations in aged cognitively normal subjects. J Neuropathol Exp Neurol 1999, 58:376-388

36. Riley KP, Snowdon DA, Markesbery WR: Alzheimer's neurofibrillary pathology and the spectrum of cognitive function: findings from the Nun Study. Ann Neurol 2002, 51:567-577

37. Wolf DS, Gearing M, Snowdon DA, Mori H, Markesbery WR, Mirra SS: Progression of regional neuropathology in Alzheimer disease and normal elderly: findings from the Nun Study. Alzheimer Dis Assoc Disord 1999, 13:226-231

38. Sampathu DM, Neumann M, Kwong LK, Chou TT, Micsenyi M, Truax A, Bruce J, Grossman M, Trojanowski JQ, Lee VM-Y: Pathological heterogeneity of frontotemporal lobar degeneration with ubiquitin-positive inclusions delineated by ubiquitin immunohistochemistry and novel monoclonal antibodies. Am J Pathol 2006, 169: $1343-1352$

39. Yang L, Gal J, Chen J, Zhu H: Self-assembled FUS binds active chromatin and regulates gene transcription. Proc Natl Acad Sci U S A 2014, 111:17809-17814

40. Kamelgarn M, Chen J, Kuang L, Arenas A, Zhai J, Zhu H, Gal J: Proteomic analysis of FUS interacting proteins provides insights into FUS function and its role in ALS. Biochim Biophys Acta 2016, 1862: 2004-2014

41. UniProt_Consortium: UniProt: the universal protein knowledgebase in 2021. Nucleic Acids Res 2021, 49:D480-D489

42. Smith VD, Bachstetter AD, Ighodaro E, Roberts K, Abner EL, Fardo DW, Nelson PT: Overlapping but distinct TDP-43 and tau pathologic patterns in aged hippocampi. Brain Pathol 2017, 28: 264-273

43. Bachstetter AD, Van Eldik LJ, Schmitt FA, Neltner JH, Ighodaro ET, Webster SJ, Patel E, Abner EL, Kryscio RJ, Nelson PT: Diseaserelated microglia heterogeneity in the hippocampus of Alzheimer's disease, dementia with Lewy bodies, and hippocampal sclerosis of aging. Acta Neuropathol Commun 2015, 3:32 
44. Giner G, Smyth GK: statmod: probability calculations for the inverse Gaussian distribution. R Journal 2016, 8:339-351

45. Dunn PK, Smyth GK: Series evaluation of Tweedie exponential dispersion model densities. Stat Comput 2005, 15:267-280

46. Nelson PT, Braak H, Markesbery WR: Neuropathology and cognitive impairment in Alzheimer disease: a complex but coherent relationship. J Neuropathol Exp Neurol 2009, 68:1-14

47. Fernández-Irigoyen J, Zelaya MV, Santamaría E: Applying mass spectrometry-based qualitative proteomics to human amygdaloid complex. Front Cell Neurosci 2014, 8:80

48. Zill P, Vielsmeier V, Büttner A, Eisenmenger W, Siedler F, Scheffer B, Möller H-J, Bondy B: Postmortem proteomic analysis in human amygdala of drug addicts: possible impact of tubulin on drug-abusing behavior. Eur Arch Psychiatry Clin Neurosci 2011, 261:121-131

49. Kékesi KA, Juhász G, Simor A, Gulyássy P, Szegõ EM, HunyadiGulyás E, Darula Z, Medzihradszky KF, Palkovits M, Penke B, Czurkó A: Altered functional protein networks in the prefrontal cortex and amygdala of victims of suicide. PLoS One 2012, 7: e50532

50. Donovan LE, Higginbotham L, Dammer EB, Gearing M, Rees HD, Xia Q, Duong DM, Seyfried NT, Lah JJ, Levey AI: Analysis of a membrane-enriched proteome from postmortem human brain tissue in Alzheimer's disease. Proteomics Clin Appl 2012, 6:201-211

51. Seyfried NT, Gozal YM, Donovan LE, Herskowitz JH, Dammer EB, Xia Q, Ku L, Chang J, Duong DM, Rees HD, Cooper DS, Glass JD, Gearing M, Tansey MG, Lah JJ, Feng Y, Levey AI, Peng J: Quantitative analysis of the detergent-insoluble brain proteome in frontotemporal lobar degeneration using SILAC internal standards. J Proteome Res 2012, 11:2721-2738

52. Gozal YM, Duong DM, Gearing M, Cheng D, Hanfelt JJ, Funderburk C, Peng J, Lah JJ, Levey AI: Proteomics analysis reveals novel components in the detergent-insoluble subproteome in Alzheimer's disease. J Proteome Res 2009, 8:5069-5079

53. Ayyadevara S, Balasubramaniam M, Parcon PA, Barger SW, Griffin WST, Alla R, Tackett AJ, Mackintosh SG, Petricoin E, Zhou W, Shmookler Reis RJ: Proteins that mediate protein aggregation and cytotoxicity distinguish Alzheimer's hippocampus from normal controls. Aging Cell 2016, 15:924-939

54. Nelson PT, Smith CD, Abner EL, Wilfred BJ, Wang W-X, Neltner JH, Baker M, Fardo DW, Kryscio RJ, Scheff SW, Jicha GA, Jellinger KA, Van Eldik LJ, Schmitt FA: Hippocampal sclerosis of aging, a prevalent and high-morbidity brain disease. Acta Neuropathol 2013, 126:161-177

55. Rall SC Jr, Weisgraber KH, Mahley RW: Human apolipoprotein E. The complete amino acid sequence. J Biol Chem 1982, 257: $4171-4178$

56. Dong LM, Wilson C, Wardell MR, Simmons T, Mahley RW, Weisgraber KH, Agard DA: Human apolipoprotein E. Role of arginine 61 in mediating the lipoprotein preferences of the E3 and E4 isoforms. J Biol Chem 1994, 269:22358-22365

57. Westerlund JA, Weisgraber KH: Discrete carboxyl-terminal segments of apolipoprotein E mediate lipoprotein association and protein oligomerization. J Biol Chem 1993, 268:15745-15750

58. Weisgraber KH: Apolipoprotein E distribution among human plasma lipoproteins: role of the cysteine-arginine interchange at residue 112. J Lipid Res 1990, 31:1503-1511

59. Tsiolaki PL, Katsafana AD, Baltoumas FA, Louros NN, Iconomidou VA: Hidden aggregation hot-spots on human apolipoprotein E: a structural study. Int J Mol Sci 2019, 20:2274

60. Pirttilä T, Soininen H, Mehta PD, Heinonen O, Lehtimäki T, Bogdanovic N, Paljärvi L, Kim KS, Kosunen O, Winblad B, Riekkinen P Sr, Wisniewski HM: Apolipoprotein E genotype and amyloid load in Alzheimer disease and control brains. Neurobiol Aging 1997, 18:121-127

61. Sanan DA, Weisgraber KH, Russell SJ, Mahley RW, Huang D, Saunders A, et al: Apolipoprotein E associates with beta amyloid peptide of Alzheimer's disease to form novel monofibrils. Isoform
apoE4 associates more efficiently than apoE3. J Clin Invest 1994, 94 : 860-869

62. Locke PA, Conneally PM, Tanzi RE, Gusella JF, Haines JL: Apolipoprotein E4 allele and Alzheimer disease: examination of allelic association and effect on age at onset in both early- and late-onset cases. Genet Epidemiol 1995, 12:83-92

63. Schmechel DE, Saunders AM, Strittmatter WJ, Crain BJ, Hulette CM, Joo SH, Pericak-Vance MA, Goldgaber D, Roses AD: Increased amyloid beta-peptide deposition in cerebral cortex as a consequence of apolipoprotein E genotype in late-onset Alzheimer disease. Proc Natl Acad Sci U S A 1993, 90:9649-9653

64. Hyman BT, West HL, Rebeck GW, Buldyrev SV, Mantegna RN, Ukleja M, Havlin S, Stanley HE: Quantitative analysis of senile plaques in Alzheimer disease: observation of log-normal size distribution and molecular epidemiology of differences associated with apolipoprotein E genotype and trisomy 21 (Down syndrome). Proc Natl Acad Sci U S A 1995, 92:3586-3590

65. Nelson PT, Pious NM, Jicha GA, Wilcock DM, Fardo DW, Estus S, Rebeck GW: APOE-[epsilon]2 and APOE-[epsilon]4 correlate with increased amyloid accumulation in cerebral vasculature. J Neuropathol Exp Neurol 2013, 72:708-715

66. Cherry JD, Zeineddin A, Dammer EB, Webster JA, Duong D, Seyfried NT, Levey AI, Alvarez VE, Huber BR, Stein TD, Kiernan PT, McKee AC, Lah JJ, Hales CM: Characterization of detergent insoluble proteome in chronic traumatic encephalopathy. J Neuropathol Exp Neurol 2018, 77:40-49

67. Johnson ECB, Dammer EB, Duong DM, Yin L, Thambisetty M, Troncoso JC, Lah JJ, Levey AI, Seyfried NT: Deep proteomic network analysis of Alzheimer's disease brain reveals alterations in RNA binding proteins and RNA splicing associated with disease. Mol Neurodegener 2018, 13:52

68. Kepchia D, Huang L, Dargusch R, Rissman RA, Shokhirev MN, Fischer W, Schubert D: Diverse proteins aggregate in mild cognitive impairment and Alzheimer's disease brain. Alzheimers Res Ther 2020, $12: 75$

69. Diner I, Nguyen T, Seyfried NT: Enrichment of detergent-insoluble protein aggregates from human postmortem brain. J Vis Exp 2017, 128:55835

70. Woltjer RL, Cimino PJ, Boutté AM, Schantz AM, Montine KS, Larson EB, Bird T, Quinn JF, Zhang J, Montine TJ: Proteomic determination of widespread detergent-insolubility including Abeta but not tau early in the pathogenesis of Alzheimer's disease. FASEB J 2005, 19:1923-1925

71. Day RJ, McCarty KL, Ockerse KE, Head E, Rohn TT: Proteolytic cleavage of apolipoprotein $\mathrm{E}$ in the Down syndrome brain. Aging Dis 2016, 7:267-277

72. Rohn TT: Proteolytic cleavage of apolipoprotein E4 as the keystone for the heightened risk associated with Alzheimer's disease. Int J Mol Sci 2013, 14:14908-14922

73. Brecht WJ, Harris FM, Chang S, Tesseur I, Yu G-Q, Xu Q, Fish JD, Wyss-Coray T, Buttini M, Mucke L, Mahley RW, Huang Y: Neuronspecific apolipoprotein e4 proteolysis is associated with increased tau phosphorylation in brains of transgenic mice. J Neurosci 2004, 24 : $2527-2534$

74. Huang Y, Liu XQ, Wyss-Coray T, Brecht WJ, Sanan DA, Mahley RW: Apolipoprotein E fragments present in Alzheimer's disease brains induce neurofibrillary tangle-like intracellular inclusions in neurons. Proc Natl Acad Sci U S A 2001, 98:8838-8843

75. Rohn TT, Catlin LW, Coonse KG, Habig JW: Identification of an amino-terminal fragment of apolipoprotein E4 that localizes to neurofibrillary tangles of the Alzheimer's disease brain. Brain Res 2012, 1475:106-115

76. Huang Y, Mahley RW: Apolipoprotein E: structure and function in lipid metabolism, neurobiology, and Alzheimer's diseases. Neurobiol Dis 2014, 72(Pt A):3-12

77. Mahley RW, Huang Y: Apolipoprotein E sets the stage: response to injury triggers neuropathology. Neuron 2012, 76:871-885 
78. Wisniewski T, Golabek A, Matsubara E, Ghiso J, Frangione B: Apolipoprotein E: binding to soluble Alzheimer's beta-amyloid. Biochem Biophys Res Commun 1993, 192:359-365

79. Wisniewski T, Lalowski M, Golabek A, Vogel T, Frangione B: Is Alzheimer's disease an apolipoprotein E amyloidosis? Lancet 1995, 345:956-958

80. Shao Y, Gearing M, Mirra SS: Astrocyte-apolipoprotein E associations in senile plaques in Alzheimer disease and vascular lesions: a regional immunohistochemical study. J Neuropathol Exp Neurol 1997, 56:376-381

81. Einstein G, Patel V, Bautista P, Kenna M, Melone L, Fader R, Karson K, Mann S, Saunders AM, Hulette C, Mash D, Roses AD, Schmechel DE: Intraneuronal ApoE in human visual cortical areas reflects the staging of Alzheimer disease pathology. J Neuropathol Exp Neurol 1998, 57:1190-1201

82. Gearing M, Schneider JA, Robbins RS, Hollister RD, Mori H, Games D, Hyman BT, Mirra SS: Regional variation in the distribution of apolipoprotein E and A beta in Alzheimer's disease. J Neuropathol Exp Neurol 1995, 54:833-841

83. Rohn TT, Day RJ, Sheffield CB, Rajic AJ, Poon WW: Apolipoprotein E pathology in vascular dementia. Int J Clin Exp Pathol 2014, 7: 938-947

84. Lemere CA, Blusztajn JK, Yamaguchi H, Wisniewski $\mathrm{T}$, Saido TC, Selkoe DJ: Sequence of deposition of heterogeneous amyloid beta-peptides and APO E in Down syndrome: implications for initial events in amyloid plaque formation. Neurobiol Dis 1996, 3:16-32

85. Kida E, Choi-Miura NH, Wisniewski KE: Deposition of apolipoproteins $\mathrm{E}$ and $\mathrm{J}$ in senile plaques is topographically determined in both Alzheimer's disease and Down's syndrome brain. Brain Res 1995, 685:211-216

86. Rebeck GW, Reiter JS, Strickland DK, Hyman BT: Apolipoprotein E in sporadic Alzheimer's disease: allelic variation and receptor interactions. Neuron 1993, 11:575-580

87. Ogeng'o JA, Cohen DL, Sayi JG, Matuja WB, Chande HM, Kitinya JN, Kimani JK, Friedland RP, Mori H, Kalaria RN: Cerebral amyloid beta protein deposits and other Alzheimer lesions in nondemented elderly east Africans. Brain Pathol 1996, 6:101-107

88. Lanfranco MF, Sepulveda J, Kopetsky G, Rebeck GW: Expression and secretion of apoE isoforms in astrocytes and microglia during inflammation. Glia 2021, 69:1478-1493

89. Diedrich JF, Minnigan H, Carp RI, Whitaker JN, Race R, Frey W 2nd, Haase AT: Neuropathological changes in scrapie and Alzheimer's disease are associated with increased expression of apolipoprotein E and cathepsin D in astrocytes. J Virol 1991, 65: $4759-4768$

90. Han SH, Hulette C, Saunders AM, Einstein G, Pericak-Vance M, Strittmatter WJ, Roses AD, Schmechel DE: Apolipoprotein E is present in hippocampal neurons without neurofibrillary tangles in
Alzheimer's disease and in age-matched controls. Exp Neurol 1994, 128:13-26

91. Richard E, Carrano A, Hoozemans JJ, van Horssen J, van Haastert ES, Eurelings LS, de Vries HE, Thal DR, Eikelenboom P, van Gool WA, Rozemuller AJ: Characteristics of dyshoric capillary cerebral amyloid angiopathy. J Neuropathol Exp Neurol 2010, 69: $1158-1167$

92. Thal DR, Capetillo-Zarate E, Schultz C, Rüb U, Saido TC, Yamaguchi H, Haass C, Griffin WST, Del Tredici K, Braak H, Ghebremedhin E: Apolipoprotein E co-localizes with newly formed amyloid beta-protein (Abeta) deposits lacking immunoreactivity against $\mathrm{N}$-terminal epitopes of Abeta in a genotype-dependent manner. Acta Neuropathol 2005, 110:459-471

93. Utter S, Tamboli IY, Walter J, Upadhaya AR, Birkenmeier G, Pietrzik CU, Ghebremedhin E, Thal DR: Cerebral small vessel diseaseinduced apolipoprotein $\mathrm{E}$ leakage is associated with Alzheimer disease and the accumulation of amyloid beta-protein in perivascular astrocytes. J Neuropathol Exp Neurol 2008, 67:842-856

94. Arélin K, Kinoshita A, Whelan CM, Irizarry MC, Rebeck GW, Strickland DK, Hyman BT: LRP and senile plaques in Alzheimer's disease: colocalization with apolipoprotein $\mathrm{E}$ and with activated astrocytes. Brain Res Mol Brain Res 2002, 104:38-46

95. Dickson TC, Saunders HL, Vickers JC: Relationship between apolipoprotein $\mathrm{E}$ and the amyloid deposits and dystrophic neurites of Alzheimer's disease. Neuropathol Appl Neurobiol 1997, 23:483-491

96. Sheng JG, Mrak RE, Griffin WS: Apolipoprotein E distribution among different plaque types in Alzheimer's disease: implications for its role in plaque progression. Neuropathol Appl Neurobiol 1996, 22:334-341

97. Cho HS, Hyman BT, Greenberg SM, Rebeck GW: Quantitation of apoE domains in Alzheimer disease brain suggests a role for apoE in Abeta aggregation. J Neuropathol Exp Neurol 2001, 60:342-349

98. Bonham LW, Desikan RS, Yokoyama JS; Alzheimer's Disease Neuroimaging Initiative: The relationship between complement factor C3, APOE epsilon4, amyloid and tau in Alzheimer's disease. Acta Neuropathol Commun 2016, 4:65

99. Berger M, Cooter M, Roesler AS, Chung S, Park J, Modliszewski JL, VanDusen KW, Thompson JW, Moseley A, Devinney MJ, Smani S, Hall A, Cai V, Browndyke JN, Lutz MW, Corcoran DL; Alzheimer's Disease Neuroimaging Initiative: APOE4 copy number-dependent proteomic changes in the cerebrospinal fluid. J Alzheimers Dis 2021, 79:511-530

100. Yin C, Ackermann S, Ma Z, Mohanta SK, Zhang C, Li Y, Nietzsche S, Westermann M, Peng L, Hu D, Bontha SV, Srikakulapu P, Beer M, Megens RTA, Steffens S, Hildner M, Halder LD, Eckstein H-H, Pelisek J, Herms J, Roeber S, Arzberger T, Borodovsky A, Habenicht L, Binder CJ, Weber C, Zipfel PF, Skerka C, Habenicht AJR: ApoE attenuates unresolvable inflammation by complex formation with activated C1q. Nat Med 2019, 25: 496-506 